\title{
Nemo auditur propriam turpitudinem allegans en la jurisprudencia contencioso-administrativa ${ }^{1}$
}

SUMARIO: I. LA REGLA NEMO AUDITUR PROPRIAM TURPITUDINEM ALLEGANS EN EL DERECHO CIVIL Y SU TRASLACIÓN AL DERECHO ADMINISTRATIVO. 1. Hay demasiadas torpezas. 2. El nemo auditur en los artículos 1305 y 1306 del Código Civil: exclusión de la restitución de lo entregado con causa torpe. 3. ¿Recepción del genuino nemo auditur en el Derecho administrativo? II. EL NEMO AUDITUR EN LA JURISPRUDENCIA CONTENCIOSO-ADMINISTRATIVA: NADIE PUEDE ALEGAR SU PROPIA TORPEZA PARA OBTENER PROVECHO Y, EN ESPECIAL, PARA CONSEGUIR UNA DECLARACIÓN DE NULIDAD QUE LE BENEFICIA. 1. Otro nemo auditur cuya relación con la torpeza es muy diferente. 2. Aplicación de este nemo auditur contra el administrado. 3. Supuestos de aplicación de este nemo auditur contra la Administración. III. CRÍTICA DE LA JURISPRUDENCIA CONTENCIOSO-ADMINISTRATIVA DEL NEMO AUDITUR: NO ES CIERTO QUE NO QUEPA ALEGAR LOS VICIOS DEBIDOS A LA PROPIA CONDUCTA; EN ESPECIAL, PUEDE HACERLO LA ADMINISTRACIÓN Y ES LO CARACTERÍSTICO DE LA NULIDAD DE PLENO DERECHO. 1. La doctrina sólo ha aceptado este peculiar nemo auditur como limitación para el administrado y respecto a vicios de anulabilidad. 2. Este nemo auditur no tiene fundamento positivo y, por el contrario, choca con los caracteres de la nulidad de pleno derecho y con el régimen de revisión de oficio. IV. SOLUCIONES SIMILARES A LAS QUE SE LLEGA CON EL NEMO AUDITUR PUEDEN Y DEBEN LOGRARSE POR OTRAS VÍAS: EN ESPECIAL, LA EQUIDAD COMO INSTRUMENTO PARA MODERAR LOS EXCESOS DE LA NULIDAD DE PLENO DERECHO.

\footnotetext{
${ }^{1}$ Grupo de investigación SEJ -196; Proyecto BJU2000-845 de DGI.
} 


\section{LA REGLA NEMO AUDITUR PROPRIAM TURPITUDINEM ALLEGANS EN EL DERECHO CIVIL Y SU TRASLACIÓN AL DERECHO ADMINISTRATIVO}

\section{HAY DEMASIADAS TORPEZAS}

Hay puntos oscuros en la regla nemo auditur propriam turpitudinem allegans. Pero, como mínimo, su estudio en Derecho civil deja claro que el significado que suele atribuírsele poco o nada tiene que ver con lo que las sentencias contencioso-administrativas que la invocan pretenden decir con ella y que más bien parecen partir de una confusión. La confusión tiene su origen en que hay demasiadas torpezas y en el mal entendimiento de la turpitudo o torpeza de que habla el aforismo. Turpitudo(-inis) significa «ignominia, deshonra, infamia, vileza, vergüenza» y, en una segunda acepción, se traduce como «fealdad, deformidad». Turpis(-e) es «vergonzoso, infame, indecente» $\mathrm{y}$ también «feo, repulsivo, repugnante». Me atrevo a imaginar que esas segundas acepciones provienen de un moralismo que, viendo muy feo hacer cosas indecentes, llegó a identificar turpitudo con fealdad. A lo que hoy llamamos normalmente torpe se llamaba en latín tardus y stolidus, y a la torpeza inertia. En el Diccionario de la Real Academia aparece todavía «turpitud» como sinónimo anticuado de torpeza y «turpe» como torpe. Pero «torpe» no tiene sólo el significado usual de «desmañado, falto de habilidad o destreza» o de «rudo, tardo en comprender». Aparecen estas otras acepciones que nos ponen en el buen camino para entender la regla: torpe es «deshonesto, impúdico, lascivo»; y algo más ampliamente «ignominioso, indecoroso, infame». Torpeza es la «calidad de torpe» y, por tanto, con las mismas acepciones variadas de torpe, incluida la que lo relaciona con lo inmoral, que es lo que aquí interesa.

En efecto, la regla nemo auditur propriam turpitudinem allegans -también formulada como nemo auditur propriam turpitudinem suam allegans o propria turpitudinem allegans non auditur o simplemente nemo auditur para los familiarizados con ella ${ }^{2}$ - tiene que ver con la inmoralidad en general. Si acaso, se puede reconocer muchas veces la tendencia a conectarla más concretamente con lo deshonesto, lo impúdico y lascivo ${ }^{3}$, pero sin excluir otras formas de inmoralidad. La re-

\footnotetext{
${ }^{2}$ Sobre las diferentes maneras con las que la regla es formulada o aludida véase M. CERDÁ Olmedo, «Nemo auditur propiam turpitudinem allegans», Revista de Derecho Privado, 1980, p. 1187. Después veremos incluso otras formulaciones que pretenden matizar el significado de la regla. En las fuentes se encuentra indistintamente propriam y propiam.

${ }^{3}$ No es impertinente recordar que no es lo mismo honrado que honesto o que, por lo menos, no lo era. F. LÁZARO CARRETER, El dardo en la palabra, Barcelona, 1997, p. 562, explica que antes estaba claro que «la honradez habitaba al norte y la honestidad al sur del ecua-
} 
DA-2002, núms. 263-264. MANUEL REBOLLO PUIG. Nemo auditur propriam turpitudinem allegans e...

gla no se agota en la lascivia y, junto con los ejemplos siempre repetidos de los pagos y regalos a meretrices y concubinas o los contratos sobre casas de tolerancia, también son típicos los de entrega de dinero a funcionarios para que resuelvan en tal sentido o a cualquier persona para que delinca, se abstenga de hacerlo o devuelva el producto de su delito. Y, de hecho, el Código Civil, en los preceptos que consagran el nemo auditur, no circunscribe la inmoralidad contemplada a la contraria a la honestidad y distingue los supuestos en que medie un delito o falta cualquiera (art. 1305) y aquellos otros de causa torpe pero no constitutivos de delito (art. 1306).

Con estas precisiones terminológicas estamos ya en disposición de afrontar el significado del nemo auditur propriam turpitudinem allegans en Derecho civil, paso previo para analizar su utilización en Derecho administrativo.

\section{El NEMO AUDITUR EN LOS ARTíCULOS 1305 y 1306 DEL CóDigo CIVIL: EXCLUSIÓN DE LA RESTITUCIÓN DE LO ENTREGADO CON CAUSA TORPE}

En Derecho civil, el nemo auditur aparece siempre como una excepción a la regla general de restitución de lo cobrado indebidamente, o sea, a la acción que tiene el que pagó indebidamente contra el accipiens. Por ello, algunos Códigos recogen esa regla al regular el pago de lo indebido o el enriquecimiento injusto ${ }^{4}$. Nuestro Código Civil, sin embargo, acoge la regla en el capítulo dedicado a la nulidad de los contratos (arts. 1305 y 1306) de modo que aparece más específicamente como una excepción a la recuperación del pago de lo indebido cuando éste tiene su origen en un contrato nulo ${ }^{5}$. Aunque con al-

dor corporal». Los académicos dieciochescos, recuerda, definían la honradez como «aquel género de pundonor que obliga al hombre de bien a obrar siempre conforme a sus obligaciones, y cumplir la palabra en todo»; mientras que honestidad era «moderación y pureza contraria al pecado de la lujuria». Pues eso: que llegados al nemo auditur las referencias a meretrices y concubinas son frecuentes y tiene uno la impresión de que la inmoralidad de la que se habla tiene mucho que ver con la lujuria o, como lo dice el mismo LÁZARO CARRETER, con el buen orden de la libido. Y no está esto del todo desorientado pues, como ya hemos visto, torpe es, según el $D R A E$, antes que genéricamente ignominioso o infame, «deshonesto, impúdico o lascivo».

${ }^{4}$ Así ocurre en Alemania (§ 817 B.G.B.) y en Suiza (art. 66 del Código de Obligaciones). También la Compilación navarra: «Causa inmoral para el que pagó. Asimismo es irrepetible lo que se da a causa de un convenio inmoral para el que pagó, aunque lo sea también para el que cobró».

${ }^{5}$ Pero, en realidad, el supuesto de la previa existencia de un contrato es sólo un supuesto dentro de una regla más general que comprende también otros casos de atribución patrimonial inmoral sin la preexistencia de contrato. Por ello, como explica J. DELGADO ECHEVERRÍA, «en el fondo, no es incorrecta su situación en el Código, pues se presenta explícitamente 
guna reiteración y diferenciaciones innecesarias, lo que establecen los artículos 1305 y 1306 CC es la exclusión de la repetición por causa torpe: hay, por tanto, una atribución patrimonial de ilicitud cualificada o torpeza (inmoralidad) en la que se niega la posibilidad de repetición, es decir, la acción del torpe para pedir la restitución de lo pagado ${ }^{6}$.

En esa exclusión consiste y se agota el nemo auditur propriam turpitudinem allegans. No hay más. En concreto, no significa ninguna limitación a la posibilidad de alegar la causa de nulidad. Por el contrario, se admite -y el nemo auditur propriam turpitudinem allegans no lo pone en cuestión- que no puede exigirse el cumplimiento del contrato nulo por inmoral y que cualquiera de las partes del contrato, incluido el tachado de turpitudo, puede alegar esa nulidad. Es decir, que, a ese efecto, sí se puede alegar la propia torpeza o inmoralidad: «Lo único que (el inmoral) no puede hacer es pedir la restitución de la atribución por él realizada» de manera que, como explica Delgado EcheverRía, sería más adecuado utilizar el brocardo «in pari causa turpitudinis cessat repetitio». Si ni siquiera en ese caso el nemo auditur limita la posibilidad de alegar el vicio de causa u

como una excepción a las acciones del tipo de la condictio indebiti establecidas en el art. 1303». Véase J. L. Lacruz Berdejo, A. Moreno Luna, J. Delgado EcheVerría y F. RiveRo Hernández, Elementos de Derecho civil, II, Derecho de obligaciones, vol. segundo, $2^{\mathrm{a}}$ ed., Barcelona, 1987, p. 381.

${ }^{6}$ Véase J. Delgado Echeverría, «Comentario al art. 1305», en Comentarios al Código Civil y Compilaciones Forales, dir. por M. AlBALADEJO y S. DíAZ AlABART, tomo XII, vol. $2^{\circ}$, $2^{a}$ edic., Madrid, 1995, p. 442. El mismo Delgado ECHEVERría, en Comentario del Código Civil, dir. por C. Paz-Ares Rodríguez, L. Díez-Picazo Ponce de León, R. Bercovitz y P.S. CORDECH, $2^{\text {a }}$ ed., Madrid, 1993, tomo II, p. 555, lo sintetiza así: «En esencia, ambos artículos (1305 y 1306) responden a un solo principio y contienen una sola norma básica, la exclusión de la repetición de lo dado por causa torpe, pero lo presentan repetitivamente...».

${ }^{7}$ Elementos de Derecho civil, op. cit., II, vol. $2^{\circ}$, p. 382, y también en los comentarios a los arts. 1305 y 1306, en Comentarios al Código Civil y Compilaciones Forales, op. cit., pp.440 y ss., passim. Incluso antes, en el comentario en la misma obra al art. 1302 CC, p. 389, anticipa: «Los arts. 1305 y 1306 niegan, en ciertos casos, a una o a ambas partes la repetición de los prestado en cumplimiento del negocio nulo ... pero en ningún caso la facultad de hacer declarar la nulidad (y así, por ejemplo, evitar el cumplimiento)». Así era ya en el Derecho romano. M. CERDÁ Olmedo, Nemo auditur..., cit. p. 1188, dice que «el Digesto enseña que el litigante podía, si el contrato no había sido aun cumplido, invocar su propia inmoralidad...». Igualmente explica en pág. 1189 que la misma solución regía en el siglo XIII pues cabía «invocar la propia inmoralidad -por vía de excepción- en el caso de periculum animae, o sea, si se ... comprometía un grave interés moral». Sin embargo, en sentido contrario, L. DíEZ-PICAZO PONCE DE LEÓN, La doctrina de los propios actos. Un estudio crítico sobre la jurisprudencia del Tribunal Supremo, Barcelona, 1963, p. 203: «Cuando la ineficacia de un contrato provenga de ser ilícita o torpe la causa, el contratante, culpable de esta ilicitud o de este carácter torpe, carece de acción para pedir la ineficacia y no puede repetir lo que hubiera dado en virtud del contrato, ni pedir el cumplimiento de lo que el otro le hubiese prometido». Ninguna objeción a las dos últimas consecuencias que señala, pero sí a la primera que, según creo, no ha reiterado DíEZ-PiCAZo en su obra posterior y que pone de manifiesto que la confusión de que aquí acusamos a la jurisprudencia contencioso-administrativa también se ha dejado sentir en Derecho civil. 
DA-2002, núms. 263-264. MANUEL REBOLLO PUIG. Nemo auditur propriam turpitudinem allegans e...

objeto inmoral, menos aún ha significado nunca que, fuera de los casos de torpeza propiamente dicha, las partes no puedan alegar los vicios invalidantes que ellas mismas hayan originado o que sean debidas a su torpeza en el sentido de falta de habilidad o destreza. Si es que alguna limitación de este tipo existe, no se ampara bajo el nemo auditur.

Una última aclaración es oportuna. La regla nemo auditur propriam turpitudinem allegans no merece ser considerada un principio general del Derecho y ello por varias razones. Por lo pronto, es más bien una excepción a una regla general, la de restitución de lo pagado indebidamente y, más en concreto, la de la eliminación de los efectos del contrato nulo con la consecuente restitución de lo entregado (art. 1303 CC). Y, además, esa excepción ni tiene un claro y sólido fundamento ni una naturaleza que permita su extensión ni conduce a consecuencias que se consideren justas en todo caso, sino más bien al contrario. Conviene recordarlo para valorar su eventual aplicación en Derecho administrativo. Por lo que se refiere al fundamento del nemo auditur, bastará recordar una de las teorías más repetidas. Es la justificación de la «indignidad procesal de quien basa su acción en un acto propio ilícito. La Justicia, se ha dicho, ante negocios infames, vuelve su rostro en un movimiento de cólera y asco» ${ }^{8}$. En la actualidad, se considera que su naturaleza es la de una pena civil, consistente en la privación de la protección jurídica, por una conducta infame, pena que pretende proteger la moral social ${ }^{9}$. Ni aquel discutible fundamento ni esta naturaleza facilitan su extensión fuera del ámbito estricto que marcan los artículos 1305 y 1306 CC. En la misma dirección apunta la cuestionable y cuestionada justicia de la regla que, a veces, conduce a soluciones poco equitativas e, incluso, según se dice,

\footnotetext{
${ }^{8}$ J. Delgado Echeverría, Elementos de Derecho civil, op. cit., II, vol. 2º, p. 383. Muy expresivamente recoge este fundamento M. CERDÁ OlmEDO, Nemo auditur..., op. cit., pp. 1193-1194: «Según este fundamento, la máxima tiene por misión evitar el planteamiento de situaciones inmorales in pretorio. La majestad de la Justicia estaría así preservada de roces infames. 'Hay algunas causas -escribe Larombière- que los magistrados no pueden oír discutir delante de ellos sin el riesgo de manchar su toga; es inadmisible que tengan que decidir, entre dos tenedores de un burdel, cuál de ellos tiene razón. Es contrario a la decencia oír hablar de semejante proceso... La Justicia se esconde con un ademán de indignación y de asco'.Y en este sentido se ha pronunciado también la jurisprudencia francesa: 'El templo de la Justicia debe cerrarse ante el que exhibe su deshonor y hace título de lo que debería ser su desvergüenza' (Tribunal de Limoges, 27 de noviembre de 1844). Estas fórmulas, y otras semejantes, indican que se trata de proteger a la Justicia, pero, en realidad, a través de la Justicia, se trata de proteger a los seres que la representan, a los Magistrados. Se tiende con ello a proteger a la Magistratura, que sufriría con la audición de los actos inmorales. Por tanto, según esta postura, la regla nemo auditur tiende a salvaguardar la dignidad del Tribunal, la respetabilidad de los jueces y el decoro de su función».

${ }^{9}$ Según J. Delgado Echeverría, «en nuestro Código, la finalidad penal es evidente en el art. 1305 y creo que tiñe todo el ámbito de éste y del siguiente artículo», en Comentarios al Código Civil y Compilaciones Forales, op. cit., XVII, vol. $2^{\circ}$, p. 446.
} 
poco morales ${ }^{10}$. Por ello, y esto sirve de colofón a lo que aquí se quiere destacar, no es de extrañar que la misma jurisprudencia civil mire con reticencias la regla y tienda a inaplicarla ${ }^{11}$. No nos pronunciaremos aquí sobre el fundamento, naturaleza y justicia o injusticia del nemo auditur, regla que, procedente del Derecho romano o del canónico, nos llegó a través de Las Partidas y consagra nuestro Código Civil en forma similar a otros Derechos. Pero lo dicho sí es suficiente para comprender que no puede ser considerado un principio general del Derecho y que tampoco hay razones para extender el ámbito de aplicación de esta regla más allá del establecido en los artículos 1305 y 1306 CC.

\section{3. ¿RECEPCIÓN DEL GENUINO NEMO AUDITUR EN EL DERECHO ADMINISTRATIVO?}

¿Puede concederse un lugar a esta verdadera y genuina regla del nemo auditur propriam turpitudinem allegans en Derecho administrativo? No conozco ningún supuesto en que los tribunales contenciosoadministrativos españoles hayan aplicado, aunque sea con adaptaciones o matizaciones, el nemo auditur y que, en consecuencia, hayan negado la restitución de las prestaciones realizadas en virtud de contrato nulo por la inmoralidad o ilicitud cualificada de la causa o el objeto, ninguna sentencia contencioso-administrativa en que se hayan invocado con alguna propiedad los artículos 1305 y 1306 CC o la regla

${ }^{10}$ M. Cerdá Olmedo, Nemo auditur..., op. cit., p. 1195, afirma que «la aplicación del adagio provoca situaciones de verdadera injusticia, en contradicción con la equidad. Efectivamente, se da una contradicción en declarar que un convenio es nulo y a la vez mantener la producción de sus efectos, en contra de la regla quod nullum est nullum producit efectum, perjudicando en muchas ocasiones, no a las dos partes culpables, sino a la más excusable de ellas, víctima quizá de la habilidad o mala fe del contrario. En tales ocasiones sería más ajustado a la moral destruir la eficacia de la convención inmoral que dejar subsistir algunos efectos favoreciendo a una de las partes». Igualmente, M. AlBALADEJO, Derecho civil, I, vol. $2^{\circ}, 14^{\mathrm{a}}$ ed., Barcelona, 1996, p. 439, afirma que lo que establece el CC con su consagración del nemo auditur «parece un saludable castigo para el que no puede obtener la restitución, pero no menos resulta un premio para el otro, que es tan culpable como aquél». Pero también hay opiniones favorables. CERDÁ OLMEDO cita en op. cit., pp. 1188 y 1189, nada menos que al mismísimo Santo Tomás de Aquino que, por lo visto, en su Summa theologica razonaba que «las ganancias de las meretrices proceden de un contrato inmoral, pero las partes acuerdan el precio voluntariamente, y privar de éste a la ramera es grave injusticia, por lo que se establece la imposibilidad de repetir lo pagado. Al cliente que no paga voluntariamente no se le puede obligar a hacerlo, pero si paga, ya no puede repetir. Se trata de mantener el statu quo como solución más justa. Santo Tomás cita otros casos en que esto ocurre, como en la simonía».

${ }^{11}$ Afirma, así, M. Albaladejo, Derecho civil, loc. cit., que «la jurisprudencia no mira con excesiva simpatía la aplicación de ese derecho a no delvolver lo que inmoralmente se recibió. Y siempre halla alguna razón para que no prospere cuando el que se queda con lo de la otra parte, no pierde a cambio lo que éste tenía de él». 
que late en ellos. Con una sola excepción, la doctrina española no se ha planteado siquiera esa posible aplicación que, salvo error, no ha suscitado controversia ni interés ${ }^{12}$. En Francia, por el contrario, el Conseil d'État ha acogido el nemo auditur en relación con los contratos administrativos y la doctrina así lo acepta y explica ${ }^{13}$. Quizá esa expe-

\footnotetext{
${ }^{12}$ Véase M. Rebollo Puig, El enriquecimiento injusto de la Administración pública, Madrid, 1995, p. 371.

${ }^{13}$ A. DE Laubadère, F. Moderne, y P. Delvolvé, Traité des contrats administratifs, $2^{\mathrm{a}}$ ed., París, 1983, tomo I, pp. 576-577, tras señalar que la regla general es el aniquilamiento de los efectos del contrato administrativo anulado, afirman: «Sin embargo, en los contratos administrativos como en los contratos civiles, la regla nemo auditur propriam turpitudinem suam allegans puede ser invocada y permitir a la parte que ha recibido rechazar la restitución a su
} cocontratante».

D. POUYAud, La nullité des contrats administratifs, París, 1991, da cumplida cuenta de las posibilidades y aplicaciones de la regla en los contratos administrativos inválidos. Refiriéndose a los contratos administrativos inmorales por su causa o por su objeto (pp. 168, 170 y 485 y ss), recoge la regla nemo auditur para expresar sólo la irrepetibilidad de las prestaciones realizadas por el contratante inmoral, pero sin que le impida alegar la causa de nulidad. Por ello, en los mismos términos en que aquí lo hemos apuntado, señala que la regla puede ser formulada más exactamente con «el adagio in pari causa turpitudinis cessat repetitio». Comienza por recordar el significado del nemo auditur en Derecho civil y las críticas de que es objeto por mantener una situación de inmoralidad o por conducir a una injusticia. Pese a «estas consecuencias individuales criticables - explica- la regla se justifica por su función preventiva en tanto que disuade de concluir contratos inmorales». Sobre esta base civilista, «el juez administrativo ha tenido igualmente ocasión de aplicar este adagio» si bien, aunque había causa ilícita, «no se puede decir que fuese inmoral en el sentido de la jurisprudencia civil» más bien orientada a identificarse con lo impúdico (p. 487). De hecho, en uno de los primeros arrêts en que se aplicó (Société H. Olive, de 25 de noviembre de 1921), ya el Comisario del Gobierno hubo de precisar que «la palabra turpitudo tiene elasticidad suficiente para calificar la participación del Sr. Olive como tal. Hay otro cambio más al introducirse en Derecho administrativo: si la jurisprudencia civil francesa aplica el nemo auditur es conocida y afecta a las dos partes, el Conseil d'État la ha admitido cuando la inmoralidad sólo concurría en el contratista y no en la Administración. Se consigue así, según POUYAUd, evitar algunos inconvenientes que presenta en Derecho civil. «La aplicación por el juez administrativo de la máxima nemo auditur tiene un sentido particular, un poco diferente de su significado en Derecho civil y que la pone al abrigo de las críticas de inmoralidad y de injusticia». Por ello afirma que se trata de un ejemplo de toma en préstamo de instituciones civiles por el Derecho administrativo pero «adecuada a condiciones especiales» (p. 488).

En todo caso, como se habrá podido comprobar, se trata en esencia de la misma regla que con ese mismo nombre conoce el Derecho civil y no de nada similar a lo que nuestros Tribunales contencioso-administrativos introducen con el nombre de nemo auditur. Si acaso, la misma POUYAUD plantea alguna ampliación en p. 422. Se pregunta allí si las causas de nulidad absoluta pueden ser invocadas siempre por los dos contratistas. Ante algunos vicios (dolo y violencia alegados por el que incurrió en ellos, y error de la otra parte), excluye esa posibilidad. Como ella misma explica, eso se basa en que tales vicios son considerados de nulidad relativa. Y añade: "Pero no es necesario para justificar esta exclusión acogerse a la teoría de la nulidad relativa. La aplicación de la máxima nemo auditur permite llegar al mismo resultado". Aquí está dándole a esta regla un sentido más amplio y distinto del que realmente tiene. Aun así, aclara que no es ésa la aplicación que ha tenido en el contencioso-administrativo francés y, menos aún, en el Derecho civil. Dice en nota: «En Derecho civil, la máxima nemo auditur no priva al contratante del derecho a invocar la nulidad, sino solamente del derecho a obtener la repetición de las prestaciones que ha realizado (...) Nos parece, sin embargo, que nada se opone a una aplicación generalizada de esta regla». Se trata, por tanto, de una opi- 
riencia francesa y las soluciones razonables a que ha conducido en los contados casos en que se ha aplicado, según lo entiende la doctrina gala, incline a aceptarlo también en nuestro Derecho administrativo. Pero, aunque no hay obstáculos insalvables a esa recepción del nemo auditur en nuestro Derecho administrativo y aunque realmente no resultaría aplicable nada más que en supuestos muy excepcionales, hay argumentos en contra. Todo cuanto antes dijimos negando que se trate de un principio general del Derecho, o sobre su carácter excepcional, y sobre su fundamento, naturaleza y discutida justicia, pone en cuestión el acierto de integrar esta regla en Derecho administrativo. Súmese a ello que lo que consagra la legislación de contratos públicos es sólo la restitución de las prestaciones realizadas en virtud del contrato nulo, sea cual fuere la causa de nulidad, incluida la de la causa torpe o inmoral (art. 65 del Texto Refundido de la Ley de Contratos de las Administraciones Públicas: «... debiendo restituirse las partes recíprocamente las cosas que hubieran recibido en virtud del mismo...», esto es, en virtud del contrato anulado); es decir, una regla equivalente a la del artículo 1303 CC, pero sin la excepción que éste contiene («...salvo lo que se dispone en los artículos siguientes») y que se plasma precisamente, entre otros, en los artículos 1305 y 1306. Además, si la causa inmoral hubiera concurrido en las autoridades y funcionarios administrativos, podría resultar injusto y absurdo que la Administración posteriormente, cuando quisiera deshacer el entuerto, no pudiera conseguir la restitución de los fondos o bienes públicos empleados. Pese a todo, los obstáculos no son insalvables y no excluimos por completo que en algunos casos de causa inmoral o de ilicitud cualificada el nemo auditur, quizá con algunas adaptaciones, pueda justificar la negación de la restitución de las prestaciones realizadas. Desde luego, en las hipótesis en que concurra delito o falta la negación de la restitución podrá venir justificada, al margen del artículo 1305 CC, porque el Código Penal prevé el comiso. Pero, como decía, ni esto ha ocupado a la doctrina española ni nuestros Tribunales se han planteado siquiera la cuestión ${ }^{14}$. Si el nemo auditur ocupa un cierto lugar en la

nión personal de la autora, que no encuentra ninguna justificación ni en la jurisprudencia ni en la doctrina civil ni administrativa y que, por lo demás, ni la misma POUYAUD desarrolla.

${ }^{14}$ Hay, sin embargo, un dictamen del Consejo de Estado que sí se pronuncia en contra de la aplicación del art. 1306 CC a los contratos administrativos, aunque con argumentos no demasiado claros ni convincentes y en un asunto en que no se sabe bien qué juego habría podido tener ese precepto: «... las consecuencias de la nulidad en materia de contratos administrativos no se ajustan a iguales principios que en la contratación civil, al margen de la regla general de la restitución recíproca (art. 47 del Reglamento de Contratación del Estado y 1303 $\mathrm{CC}$ ). Y ello es así porque en la contratación administrativa incide un elemento diferenciado, el interés público, que impide considerar sólo la conmutatividad de las prestaciones recíprocas de las partes para atender también a la satisfacción de esos intereses generales en juego; y porque, asimismo, la voluntad de la Administración no es autónoma como la del particular 
DA-2002, núms. 263-264. MANUEL REBOLLO PUIG. Nemo auditur propriam turpitudinem allegans e...

jurisprudencia contencioso-administrativa es porque, bajo ese título, se alude a otra cosa.

\section{EL NEMO AUDITUR EN LA JURISPRUDENCIA CONTENCIOSO-ADMINISTRATIVA: NADIE PUEDE ALEGAR SU PROPIA TORPEZA PARA OBTENER PROVECHO Y, EN ESPECIAL, PARA CONSEGUIR UNA DECLARACIÓN DE NULIDAD QUE LE BENEFICIA}

\section{OTRO NEMO AUDITUR CUYA RELACIÓN CON LA TORPEZA ES MUY DIFERENTE}

Aunque, al parecer, no siempre los Tribunales civiles han invocado con propiedad el nemo auditur ${ }^{15}$, nada comparable a su utilización en las sentencias contencioso-administrativas en las que desaparece toda relación con el sentido originario del adagio y aparece una nueva regla de contornos imprecisos, consecuencias variadas y fundamento y acierto muy discutibles. En esa extraña nueva regla el presupuesto de hecho no tiene ya nada que ver con la inmoralidad, ni menos aún, concretamente, con lo deshonesto y lascivo, pues la torpeza de la que habla el brocardo se entiende, en el mejor de los casos, como falta de habilidad o destreza o, incluso, simplemente, con cualquier error o ilegalidad. Aunque se tenga una moral muy estricta, se estará de acuerdo en que la torpeza de que aquí se habla no tiene nada que ver con aquélla y, menos todavía, con lo deshonesto o impúdico. Y si, pese a todo, se quiere encontrar alguna inmoralidad o falta de ética habrá que buscarla, si acaso, en el cambio de comportamiento, en la contradicción con la propia conducta... pero no, como en el auténtico

\footnotetext{
en una relación civil sino siempre sujeta y ajustada a Derecho (...) Y esa diferencia apuntada proviene de que los elementos típicos del contrato administrativo vienen modulados en cierta manera respecto de los civiles; la causa del contrato administrativo no es el correlato exacto de la causa contractual civil, ya que en la causa de la contratación pública se inserta necesariamente el elemento final de la actuación administrativa. Cuando concurre una prohibición legal no se afecta de modo propio y directo a la causa del contrato en el sentido civil (haciéndola torpe), sino que se pone de relieve una grave tacha del fin del contrato por la quiebra que la concurrencia de esa prohibición supone para el logro de los intereses públicos siempre presentes en toda actuación administrativa. Por ello el régimen jurídico de tal nulidad no puede establecerse trasladando una norma civil que contempla otro fallo estructural diferente en el contrato. Así, ni la regla del art. 1303 del Código Civil ni la del art. $1306.2^{\circ}$ del mismo cuerpo legal (que es pieza esencial del nemo auditur como se ha explicado aquí) tendrían pleno y literal acomodo ante dicha situación» (dictamen núm. 2930/95 de 14 de marzo de 1996, Recopilación de doctrina legal de 1996, núm. 98).

${ }^{15}$ J. Delgado EcheverRía, en Elementos..., op. cit, tomo II, vol. $2^{\circ}$, p. 385, y también en Comentarios al Código Civil y Compilaciones Forales, op. cit., tomo XVII, vol. $2^{\circ}$, pp. 453 454.
} 
nemo auditur, en la actuación originaria, en el contrato nulo o, más concretamente, en la atribución patrimonial con causa torpe. Tampoco las consecuencias tienen nada que ver, desde luego, con la que hemos visto en Derecho civil de negación de la restitución de lo entregado con causa inmoral sino que, dentro de la imprecisión de tan extraña regla inventada, suponen más o menos una limitación para invocar con éxito algunas alegaciones jurídicas que, en otro caso, sí se considerarían procedentes. En el tiempo del marketing, un buen eslogan puede servir para consagrar lo que sugiere aunque sugiera algo muy distinto de lo que realmente dice. Y eso es lo que ha pasado con el nemo auditur propriam turpitudinem allegans que ha pasado a significar aquello a lo que más o menos suena.

Para intentar delimitar mejor qué pretenden decir los Tribunales con su errónea alusión al nemo auditur hay que descender ya al análisis de las sentencias. Y no cabe descartar que, salvo que ninguna de ellas se refiere a la negación de la restitución de lo entregado con causa inmoral, no tengan mucho más en común pues, una vez que se pierde el rigor, las variedades del error son casi infinitas. A cambio, lo que el nemo auditur pierde en contenido lo gana en categoría porque, de ser una regla excepcional muy discutida y criticada, pasa a ser para algunas de las sentencias que lo citan nada menos que un principio general del Derecho.

\section{APLICACIÓN DE ESTE NEMO AUDITUR CONTRA EL ADMINISTRADO}

En algunas ocasiones, aunque muchas menos que la Administración, es el administrado quien ve limitadas por el nemo auditur sus posibles alegaciones. Así ocurre en la STS de 20 de mayo de 1992 (RJ 5092) que niega al recurrente la posibilidad de alegar la inconstitucionalidad de la Orden Ministerial en la que inicialmente basó su solicitud: «... si el expediente administrativo del caso se tramita y decide aplicando la Orden Ministerial de 26-4-1971, ello es porque fue instado por la recurrente, por lo cual ésta carece de legitimación para, posteriormente y una vez que tal resolución le fue desfavorable, olvidándose de sus propios actos, pretender la inconstitucionalidad de la Orden Ministerial..., pues una tal conducta procesal prohibida viene por el artículo 115.2 de la Ley de Procedimiento Administrativo (de 1958; en adelante LPA/58) en donde se plasma el conocido principio de nemo auditur propiam turpitudinem allegans...». La invocación del nemo auditur no puede ser más impertinente porque claro está que el peticionario ninguna culpa tenía de la inconstitucionalidad de la Orden Ministerial y tampoco de que fuese la aplicable al caso y de haber basado su pretensión en ella porque, en principio, no tenía, parece, 
DA-2002, núms. 263-264. MANUEL REBOLLO PUIG. Nemo auditur propriam turpitudinem allegans e...

Nemo auditur propriam turpitudinem allegans...

otro remedio ${ }^{16}$. Y, puestos a invocar el nemo auditur donde, ni siquiera deformado y retorcido viene a cuento, otras sentencias advierten de que no sufre indefensión el demandante que ve rechazada una prueba documental cuando pudo y debió acompañar los documentos a su demanda: «sin que pueda válidamente alegar indefensión la parte causante de ella, conforme al adagio nemo allegans turpitudinem suam est audiendus» (STS de 18 de julio de 1995, RJ 6115). Verdaderamente, como es obvio, no hay indefensión en tales supuestos, pero la referencia a nuestra regla es totalmente superflua e incorrecta: naturalmente no sufre indefensión quien pudo perfectamente defenderse y no lo hizo por su negligencia o error.

Más atinada e ilustrativa -aunque, desde luego, dentro de la confusión generalizada sobre la turpitudo y el significado originario de la regla- es la sentencia del Tribunal Superior de Justicia de Castilla-La Mancha de 22 de julio de 1999 (RJCA 3106). Los hechos son pintoresco: el actor había resultado electo concejal por la candidatura «Unión

\footnotetext{
${ }^{16} \mathrm{Si}$ acaso, podría haber comenzado por recurrir la Orden Ministerial incluso antes de saber cómo se aplicaría y si sus defectos le afectarían personalmente. Pero exigir ese comportamiento a los administrados es en muchos casos absurdo e injusto. Esta sentencia, en el fondo, según creo, se aproxima a aquella jurisprudencia que niega a quienes participan en los procedimientos de selección de contratistas o de personal de la Administración la posibilidad de impugnar después la convocatoria, las bases, el pliego o cualquier acto preparatorio o los que sean consecuencia directa de ellos, jurisprudencia que frecuentemente se pretende justificar en la doctrina de los actos propios. Véase al respecto L. Cosculluela MonTANER, $M a-$ nual de Derecho administrativo, $12^{\mathrm{a}}$ ed., Madrid, 2001, p. 406: «En el supuesto de que el contratista no impugne la resolución que aprueba el procedimiento de aprobación del contrato y presente sus proposiciones se entiende, por la regla non venire contra factum proprium, que consiente y por tanto acepta tal resolución, que deviene firme e inatacable»; J. GONZÁLEZ PÉREZ, El principio general de la buena fe en el Derecho administrativo, $2^{\mathrm{a}}$ ed., Madrid, 1989, p. 155, nota 78. En contra de esa jurisprudencia, por lo menos en supuestos de nulidad absoluta, me he manifestado en «La invalidez de los contratos administrativos», publicado en la obra colectiva coordinada por F. CASTILLO BLANCO, Estudios sobre la contratación en las administraciones Públicas, Granada, 1996, pp. 419-420, como antes lo había hecho J.L. PIÑAR MAÑAS, «El sistema de garantías para la efectiva implantación de la apertura de la contratación pública comunitaria», en la obra colectiva La protección jurídica del ciudadano (procedimiento administrativo y garantía jurisdiccional). Estudios en homenaje al Profesor Jesús González Pérez, Madrid, 1993, I, p. 783; J. M. ${ }^{a}$ BAÑo LEÓN, «Proyecto de Ley de Contratos de las Administraciones Públicas», Anuario del Gobierno Local, 1995, p. 69: «... hay que superar la vieja doctrina de que la participación en el concurso supone la aceptación de las cláusulas»; y pág. 74: «habrá de quebrarse la doctrina jurisprudencial que veda impugnar indirectamente el pliego de condiciones...»; y sobre todo el mismo GonZÁlEZ PÉREZ, op. cit., pp. 155-156, que además cita como doctrina correcta la contenida en la STS de 9 de mayo de 1975 que se aparta de la mayoritaria en estos términos: «... tampoco puede sostenerse la aplicación a este caso de la reiterada doctrina jurisprudencial de que la aceptación de las condiciones del pliego y el consentimiento prestado a la convocatoria impiden la impugnación del concurso, pues este poder de atracción vinculante sólo puede admitirse cuando exista una adaptación a la normativa aplicable, más no en cambio cuando ... se incurre en omisiones o defectos sustanciales que afectan a su validez, ya que entonces se está por encima de los intereses personales y ... por consiguiente su enmienda o corrección no depende de la voluntad de las partes...».
} 
por Tresjuncos»; el día de constitución de la nueva Corporación, por razones que no hacen al caso, se negó a prestar juramento pero, pese a ello, se aceptó que se presentase como candidato a Alcalde de Tresjuncos y que votase en la elección que, al parecer, no condujo a los resultados apetecidos. Tras comprobarlo, impugnó la constitución del Ayuntamiento y la elección de Alcalde, todo ello viciado precisamente, según su argumentación, porque le habían permitido a él votar y ser candidato pese a no haber prestado juramento. Para la sentencia «este alegato ... incurre en lo manifiestamente inaceptable. Pretende alegar su propio incumplimiento de la legalidad para lograr la anulación del acto de constitución del Ayuntamiento. Admitir tal pretensión sería premiar la ilegalidad, incitar al incumplimiento de las normas y admitir la más grosera vulneración del principio de que nadie puede ir en contra de sus propios actos». Y añade, ya con cita expresa de nuestro aforismo, lo siguiente:

«Es un principio general del Derecho (art. 1.4 CC) ... el de que nadie puede contradecir sus actos anteriores, principio que se concreta en otro según el cual nadie puede alegar en su provecho su propia torpeza (nemo auditur turpitudinem suam allegans), principio que emana, entre otros, de los arts. 1302, 1305, 1306, 1764 y 1270 CC».

Con esa base, concluye que «las consecuencias de quien voluntariamente dejase de cumplir con sus obligaciones y pese a ello participase indebidamente en una votación sólo a él le pueden perjudicar y desde luego no puede pretender obtener provecho de las mismas».

\section{SuPUESTOS DE APLICACIÓN DE ESTE OTRO NEMO AUDITUR CONTRA LA ADMINISTRACIÓN}

\subsection{Nemo auditur y notificaciones erróneas. Primeras y sorprendentes aplicaciones del artículo 110.3 de la LRJPAC en contra de la Admi- nistración}

Sirven para empezar y orientar sobre los derroteros de esta jurisprudencia las sentencias que acuden al nemo auditur para rechazar la causa de inadmisibilidad del recurso contencioso-administrativo alegada por la Administración por la falta de un recurso administrativo previo cuando ello fue debido a la notificación errónea de la propia Administración que indujo la equivocación del recurrente. Ejemplo de ello, entre otras, es la STS de 20 de mayo de 1992 (RJ 5095):

«... es de retener que en la notificación de la resolución administrativa materia de impugnación ... la Administración actuante 
DA-2002, núms. 263-264. MANUEL REBOLLO PUIG. Nemo auditur propriam turpitudinem allegans e...

indica al administrado interesado que la vía impugnatoria frente a la resolución que se le notifica es la jurisdiccional ante este Tribunal Supremo, de tal modo que si el notificado siguió las indicaciones de la Administración notificante y por ello acudió ante esta Sala, la Administración que indujo a tal conducta, carece de legitimación para posteriormente alegar en su provecho y defensa la admisibilidad (sic) que ahora nos ocupa pues una tal postura procesal prohibida viene por el art. 115.2 de la Ley de Procedimiento Administrativo (de 1958) cuando expresamente incorpora a nuestro ordenamiento jurídico positivo el conocido principio de que nemo auditur propiam turpitudinem allegans ${ }^{17}$ ».

La supuesta consagración de este hipotético principio en el artículo 115.2 LPA/58 se reitera en otras muchas sentencias, como ya hemos visto y se seguirá viendo. Recordemos que el referido artículo 115.2 LPA/58 decía literalmente esto: «Los vicios y defectos que hagan anulable el acto no podrán ser alegados por los causantes de los mismos». El precepto tuvo la fortuna de pasar a la Ley 30/1992, de 26 de noviembre, no sólo con idéntica redacción sino hasta con la misma numeración, artículo 115.2. Sólo tras la reforma introducida por la Ley 4/1999 ha cambiado el número y se ha mejorado mínimamente la redacción. Es ahora, tras la reforma de 1999, el artículo 110.3 de la Ley de Régimen Jurídico de las Administraciones Públicas y del Procedimiento Administrativo Común (en lo sucesivo, LRJPAC) el que establece que «los vicios y defectos que hagan anulable un acto no podrán ser alegados por quienes los hubieren causado». Pues bien, por sorprendente que resulte, según la sentencia transcrita, ese precepto incorpora al ordenamiento positivo «el conocido principio de que nemo auditur propiam turpitudinem allegans» y ése es justamente el que im-

${ }^{17}$ Con la misma finalidad, se acude al nemo auditur, por ejemplo, en las SSTS de 11 de julio de 1988 (RJ 5883), 28 de enero de 1986 (RJ 70), 21 de noviembre de 1985 (RJ 5570)... También es frecuente la invocación del nemo auditur en relación con las notificaciones erróneas en las sentencias de los tribunales inferiores: sentencia de la Audiencia Nacional de 16 de febrero de 1999 (RJCA 3481), sentencia del Tribunal Superior de Justicia de Cantabria de 24 de septiembre de 1998 (RJCA 3950)...

Próximos a este tipo de supuestos son aquellos, casi más sorprendentes, en que el nemo auditur sirve para rechazar la causa de inadmisibilidad del acto consentido y firme, alegada por la Administración, cuando ésta no notificó a los interesados la resolución. Se lee así, por ejemplo, en la STS de 17 de mayo de 1989 (RJ 2104) lo siguiente: «... notificación ésta que, al no ser nunca efectuada por la Administración, no cabe luego que ésta argumente que debido a su omisión se produjo la firmeza del acto cuya notificación se había precisamente solicitado al objeto dicho de poder ser recurrido en forma, dado el principio jurídico de que nemo auditur propiam turpitudinem allegans». Creo que huelga explicar la impertinencia de invocar aquí el aforismo y que para justificar que no se puede considerar acto consentido y firme a uno no notificado hay argumentos elementales que nada tienen que ver con la propia torpeza. Por ello, tampoco prosperaría esa alegación del acto consentido aunque la alegase un codemandado que no tuviese ninguna culpa de que no se hubiese notificado el acto. 
pide a la Administración alegar la causa de inadmisibilidad en cuestión. Claro está que si eso es así, están equivocados los civilistas que lo veían en los artículos 1305 y 1306 CC que se parecen bien poco al artículo 115 de la Ley de Procedimiento Administrativo de 1958 o al actual artículo 110.3 LRJPAC. De ser verdad que en estos preceptos se incorpora el nemo auditur propiam turpitudinem allegans, habrá que aceptar, al menos, que no es el «conocido», aunque así lo califique la sentencia, sino otro que, al parecer, pugna por desbancar al genuino, acreditado y legítimo. Pero, aun prescindiendo de ello, no puede pasarse por alto que no es nada fácil encontrar relación entre lo que decía el artículo 115.2 LPA/58 o el actual artículo 110.3 LRJPAC y que la Administración no pueda alegar causas de inadmisibilidad basadas en la conducta del administrado a que ha conducido la notificación errónea porque esto no tiene nada que ver con un vicio de anulabilidad de un acto. Tampoco puede decirse que la Administración alegue en estos casos su propia torpeza -aun identificada con la simple comisión de errores- sino exactamente lo contrario: lo que pretendía era no tener en cuenta su propio error. De hecho, la misma conclusión de la admisibilidad de recursos contencioso-administrativos interpuestos con algún error inducido por una notificación con indicaciones equivocadas se encuentra en otras sentencias y en la doctrina sin que aparezca la más mínima alusión ni a esos preceptos de la legislación procedimental administrativa ni al nemo auditur ${ }^{18}$. Si acaso, se pone esa solución en relación con el principio de buena fe en el que, con alguna dificultad, podría encontrarse su fundamento ${ }^{19}$. De todas formas, conviene todavía observar que probablemente la esencia de esta doctrina no esté en que sea la propia Administración autora de la notificación errónea la que luego alega la causa de inadmisibilidad. No creo que la solución cambiase si la alegara, por ejemplo, un particular codemandado que ninguna culpa tuviera en los errores de la notificación. Y si realmente es así, se comprende que poco tiene que ver todo

\footnotetext{
${ }^{18}$ Véase M. ${ }^{a}$ R. AlONSO IBÁÑEZ, Las causas de inadmisibilidad en el proceso contenciosoadministrativo; Madrid, 1996, pp. 220-221, y F. GONZÁlEZ NAVARRO, Derecho administrativo español, tomo III, Pamplona, 1997, pp. 976-977.

${ }^{19}$ Véase J. GONZÁLEZ PÉREZ, El principio general de la buena fe en el Derecho administrativo, op.cit., pp. 82 y ss. Incluso así, el mismo GónZALEZ PÉREZ reconoce que «es discutible hasta qué punto es ésta una consecuencia del principio de buena fe». Con carácter más general, en pp. 172-173, presenta como concreción procesal del principio de buena fe a la «improcedencia de alegar la inadmisibilidad por motivos provocados por la propia parte demandada». En ningún caso, aparece como justificación de ello el nemo auditur. M. ${ }^{a}$ R. ALONSO IBÁÑEZ, Las causas de ..., op. cit., p. 316, cita concretamente como fundamento de esta jurisprudencia sobre «el rechazo de la inadmisibilidad en los supuestos de conducta irregular de la Administración pública que contribuye a la existencia de defectos procesales» el principio venire contra factum proprium non valet a lo que hay que añadir, en cualquier caso, la tutela judicial efectiva y el principio pro actione.
} 
DA-2002, núms. 263-264. MANUEL REBOLLO PUIG. Nemo auditur propriam turpitudinem allegans e...

esto con una limitación subjetiva de las alegaciones por la culpa o el error anterior sino con un cierto valor objetivo que se otorga a lo indicado en las notificaciones y a la confianza que generan y que quiere protegerse.

\subsection{El nemo auditur ante la falta de notificación de los actos favorables}

Hay otro tipo de aplicaciones del nemo auditur también relacionadas con las notificaciones pero muy distintas de las anteriores. Se trata simplemente de reconocer eficacia a ciertos actos administrativos aunque no hayan sido notificados por la Administración. Ilustra esta jurisprudencia la STS de 9 de noviembre de 1981 (RJ 5025) ${ }^{20}$. Los hechos que interesan se pueden resumir así: antes de acordarse la suspensión del otorgamiento de licencias, el Ayuntamiento había concedido expresamente determinadas licencias de demolición, pero no lo había notificado; basándose en esa falta de notificación, pretendía el Ayuntamiento que la licencia no era todavía eficaz y que, por tanto, le afectaba la suspensión de licencias acordada. Frente a ello, dice la sentencia que «los efectos de los actos administrativos se producen desde la fecha en que se dictan, como nos enseña el art. 45.1 de la citada LPA (de 1958; ahora art. 57.1 LRJPAC), y sin que la circunstancia de que el acuerdo ... (el que concedía la licencia) no hubiera sido notificado al interesado altere, en perjuicio de éste, la eficacia temporal de aquél, pues tal omisión no puede ser alegada por la Administración causante de la misma, a tenor del principio nemo auditur propriam turpitudinem allegans plasmado en el art. 115.2 de la reiteradamente citada LPA». Para llegar a la correcta conclusión de la sentencia, bastaba con afirmar sencillamente que, a diferencia de los actos que imponen deberes, los actos que reconocen derechos, por lo general, son eficaces desde que se dictan ${ }^{21}$. Nada tiene que ver con esto un hipoté-

\footnotetext{
${ }^{20}$ Asimismo, aunque más confusamente, otras como la STS de 19 de febrero de 1992 (RJ 2909).

${ }^{21}$ Así lo explica G. VedEL, Derecho Administrativo, trad. española, Madrid, 1980, p. 160. Y no sólo no hay inconveniente en aplicar ese régimen en el Derecho español sino que así lo ha hecho ya el propio TS en algún caso sin acudir, desde luego, al nemo auditur. Sirva para probarlo su sentencia de 18 de febrero de 1998 (RJ 1224) según la cual, también en un supuesto de otorgamiento de licencia no notificado, la regla de la eficacia demorada a la notificación «se refiere sólo a los actos no favorables al interesado, pues en otro caso quedaría a merced de la Administración demorar sine die los efectos de los actos favorables con solo no notificarlos». Véase F. LÓPEZ MERINO, La notificación en el ordenamiento jurídico español, Granada, páp. 312-313, y R. BOCANEGRA SIERRA, Lecciones sobre el acto administrativo, Madrid, 2002, pp. 113-114. M. BELADIEZ RoJo, Validez y eficacia de los actos administrativos, Madrid, 1994, pp. 171 a 174, distingue, incluso para un mismo acto, diferentes efectos: unos se producen desde que se dicta (p. ej. obligación de conservación para la Administración de los actos favorables) y otros requieren la notificación.
} 
tico incumplimiento del deber de notificar por parte de la Administración, incumplimiento que puede no existir: la notificación debe hacerse en el plazo de diez días (art. 58.2 LRJPAC); mientras no transcurra ese plazo, la Administración no ha incumplido nada y, sin embargo, tampoco puede entenderse que el acto favorable no sea eficaz. Si la justificación hubiera de encontrarse en alguna «torpeza» de la Administración se llegaría a la conclusión de que antes de que transcurran los diez días sí cabría aceptar la ineficacia del acto favorable no notificado. Así que, en definitiva, la alusión al nemo auditur no sólo es impertinente y superflua sino que, además, conduce a conclusiones injustas.

\subsection{Nemo auditur $y$ silencio administrativo}

En algún caso se argumenta el nemo auditur para impedir que la Administración se beneficie del incumplimiento del deber de resolver expresamente. Curioso es el supuesto de la STS de 16 de julio de 1997 (RJ 6034) en el que era la Administración la que basaba su decisión -en concreto, declaración de caducidad de una licencia de obra- en un previo silencio positivo. Frente a ello, el recurrente argumentó que como su solicitud nunca se resolvió, seguía sin transcurrir el plazo de caducidad de la licencia. Según lo explica la sentencia, «se alega ... que, aun en el supuesto de que el silencio positivo se hubiera producido, sus efectos pueden ser alegados en su favor por el administrado, pero no (como ocurría aquí) por la Administración en contra de aquél»; todo ello «con apoyo en el art. 115.2 LPA» de 1958 que, para la sentencia apelada, como para otras muchas, es «aplicación positivada del principio general del Derecho expresado en el brocardo allegans propiam turpitudinem non auditur...». Y, en efecto, esto es lo que acepta el TS al decir que tanto en el caso del silencio negativo como en el del positivo «no es lícito a la Administración beneficiarse del incumplimiento de su deber de resolver expresamente porque hay, en efecto, un principio general del Derecho (expresado con distintas formulaciones en el art. 115.2 LPA y en el art. 1288 CC) según el cual ningún infractor puede alegar en su propio beneficio su incumplimiento de las normas, principio a través del cual se pretende introducir en el campo jurídico un valor ético. Y la diferencia de naturaleza entre el silencio negativo (que es una pura ficción en favor del administrado) y el silencio positivo (que provoca un auténtico acto administrativo) no les hace distintos a este respecto ya que en ambos casos el silencio se ha producido por una conducta ilegítima de la Administración que no puede redundar en su beneficio». Discutible es que el silencio positivo no pueda de ninguna forma ser invocado por la Administración 
DA-2002, núms. 263-264. MANUEL REBOLLO PUIG. Nemo auditur propriam turpitudinem allegans e...

por la única razón de que, naturalmente, tiene su origen en el incumplimiento de su deber de resolver expresamente en el plazo. Por esa vía se llegaría al absurdo de que la Administración tampoco pueda alegar en contra del administrado el silencio negativo que también tiene su causa en un incumplimiento administrativo. Pero, con independencia de ello, debe destacarse el hallazgo de que el artículo 115.2 LPA/1958 y el artículo 1288 CC (que establece que la interpretación de las cláusulas oscuras de un contrato no deberá favorecer a quien hubiera ocasionado la oscuridad) expresan el mismo «principio general del Derecho según el cual ningún infractor puede alegar en su propio beneficio su incumplimiento de las normas» ${ }^{22}$.

\subsection{El nemo auditur ante los defectos de forma y de competencia: en especial, la Administración no puede alegar los vicios invalidantes - ni siquiera los de nulidad de pleno derecho-que ella misma originó}

El nemo auditur se ha invocado también ante otros defectos de forma cometidos por la Administración y justamente para impedir a ésta que los alegara con éxito como vicios de su propia actuación y en perjuicio del administrado. En realidad, esta jurisprudencia ofrece muchas variantes ${ }^{23}$. Pero entre ellas destaca por su abundancia e impor-

22 También se relaciona al nemo auditur con una falta de resolución administrativa expresa en la STS de 26 de noviembre de 1992 (RJ 8968) aunque en este caso sin que mediara silencio administrativo. Un arquitecto, cumpliendo el contrato, entregó el anteproyecto de Rectorado de la Universidad de Extremadura sin que la Administración adoptase ningún acuerdo. Ante ello, procedió a la redacción y entrega del proyecto y, después, a reclamar la retribución que la Administración negó alegando que nunca había aprobado el anteproyecto. Ante ello, la sentencia dice que «al no haber la Administración contratante, ni puesto reparo alguno, ni denegado nunca de forma expresa la aprobación del anteproyecto ... no puede la Administración que así incumple sus obligaciones formales obtener consecuencias favorables de una tal conducta a tenor del conocido principio de que nemo auditur propiam turpitudiem allegans...».

${ }^{23}$ Por ejemplo, STS de 23 de septiembre de 1992 (RJ 7058): la Administración, ante la solicitud de convalidación de un título universitario extranjero, no pidió, pese a ser preceptivo, el informe de la Comisión Mixta prevista al efecto en el correspondiente Convenio de Cooperación Cultural, omisión que luego arguye para negar que se conceda la convalidación. Pero la sentencia afirma: «... el defecto o vicio de procedimiento resultante de tal proceder no puede producir efectos dañosos para los administrados, tal y como establece el art. 115.2 (de la LPA/58) cuando en él se recoge el principio jurídico nemo auditur propiam turpitudinem allegans».

La misma idea late en la STS de 22 de marzo de 1988 (RJ 2462) ante la suspensión de iniciación de las obras por falta de licencia municipal y otros problemas, suspensión que no fue formalmente declarada pero que, de hecho, se produjo. De ahí que se entienda que el contratista cumplió en el plazo pactado contado desde que realmente pudo comenzar: «... el hecho de que la autoridad u órgano que celebró el contrato no dictase resolución al efecto, en modo alguno puede perjudicar a quien, como la recurrente, es ajena a tal omisión o incumplimiento 
tancia la que, en resumen, consiste en afirmar que la Administración no puede alegar la nulidad de sus actos y contratos cuando se basa en su propia actuación ilegal. Así se ve, por ejemplo, en la STS de 22 de octubre de 1991 (RJ 7536). En síntesis, el supuesto era éste: en un contrato de obras cuya ejecución no excedía de seis meses se había pactado la revisión de precios, pero ello sin que la Administración hubiera pedido el informe de la Junta Consultiva de Contratación que era preceptivo para incluir esa cláusula en contratos de esa corta duración; la Administración alegó esa omisión procedimental para justificar la invalidez de la cláusula y para, en consecuencia, negarse a aplicarla y a pagar la cantidad resultante. Pero para la sentencia, si «la Administración formalizó el contrato de obras sin cumplimentar tal requisito del informe previo sibi imputet, sin que pueda hacer recaer las consecuencias de sus propias irregularidades formales en su contraparte, tal y como nos enseña el artículo 115.2 LPA (de 1958) ... recogiendo el viejo principio general de derecho de nemo auditur propiam turpitudinem allegans.... ${ }^{24}$.

Un paso más se da cuando los Tribunales rechazan la anulación de un acto administrativo por vicio de incompetencia del órgano que

de obligaciones legales, como específicamente nos enseña el art. 115.2 LPA (de 1958) cuando recoge el principio jurídico de que nemo auditur propiam turpitudinem allegans».

También la STSJ de Castilla-La Mancha de 7 de abril de 1999 (RJCA 1523) utiliza el nemo auditur para afirmar el cumplimiento del contratista y su derecho a los intereses con el aliciente adicional de conectarlo con el art. 1306 CC (o sea, el que recoge el verdadero y tradicional nemo auditur) aunque no tenga nada que ver con lo afirmado: «en virtud de la regla nemo propiam turpitudinem allegare potest (art. 1306 CC), el Ayuntamiento no puede alegar su propia torpeza para pretender ahora la carga de la culpa al contratista, pues a aquél corresponde obtener los terrenos y las autorizaciones pertinentes...».

El mismo Tribunal, en su sentencia de 7 de enero de 2000 (RJCA 22), se sirve de la regla para negar que la Administración pueda no devolver la fianza al contratista que, al parecer, había ejecutado con defectos las obras, por la razón de que la Administración no había reaccionado ante ello conforme a las previsiones de la legislación de contratos: «esas deficiencias de procedimiento ... demorando indefinidamente una recepción provisional y luego negándose a la recepción definitiva, pero sin comunicar al contratista las deficiencias, ... no pueden oponerse ahora en perjuicio del contratista de conformidad con el aforismo nemo turpitudinem allegans». Pero no se entiende el razonamiento: lo que el Ayuntamiento alegaba eran los defectos de construcción y el único problema para aceptar que, en efecto, no procedía devolver la fianza era que no había comunicado formalmente al contratista tales defectos por los que se negaba a recibir la obra; el Ayuntamiento no alegaba su propio incumplimiento de las normas (la falta de recepción) sino los defectos de la prestación del contratista; y lo que la sentencia hace, en el fondo, es dar por perfectamente cumplidas las obligaciones del contratista por el hecho de que la Administración no denunció con las formalidades necesarias el incumplimiento. Francamente, la relación con el nemo auditur -incluso con su peculiar versión administrativa- no se ve con claridad.

${ }^{24}$ Semejante es la STS de 1 de febrero de 1982 (RJ 603): «... no es aceptable que el Ayuntamiento alegue la improcedencia de la revisión de precios por haber infringido lo establecido en el art. 2 de dicho Decreto-Ley respecto a la exigencia de resolución motivada para la inclusión de la cláusula» porque «es principio general de Derecho -admitido jurisprudencialmente e inspirador del art. 115.2 LPA (de 1958)- que allegans propiam turpitudinem non auditur». 
DA-2002, núms. 263-264. MANUEL REBOLLO PUIG. Nemo auditur propriam turpitudinem allegans e...

actuó si ello es alegado por la propia Administración. Ejemplifica esta afirmación la STS de 23 de noviembre de 1984 (RJ 5956). Simplificando mucho, se trataba de que la Corporación Metropolitana de Barcelona se negaba a cumplir un convenio expropiatorio alegando que el órgano que intervino (la llamada Comisión Administrativa) no era el que tenía en la Corporación la competencia expropiatoria (que correspondía al Consejo Metropolitano). Junto a invocaciones a la buena fe, no respetada por la Corporación según la sentencia, se afirma además:

«Que ante la situación creada por la actividad administrativa es ... aplicable el principio propiam turpitudinem allegans non auditur por el que no cabe alegar ni ampararse en los propios errores...».

Con ese significado, hay otras muchas sentencias contencioso-administrativas que proclaman el mismo «principio» de que la Administración no puede alegar los vicios que ella misma ha originado sin el equivocado envoltorio del nemo auditur propriam turpitudinem allegans, pero ya sin limitarlo a defectos de forma o competencia incluyendo algunos que inequívocamente son de nulidad como, por ejemplo, la falta de consignación presupuestaria. Basten algunos ejemplos:

— STS de 9 de marzo de 1966 (RJ 1162): «... no es lícito invocar un motivo invalidatorio que ... derivaría de irregularidades de la propia Administración frente al administrado...».

— SSTS de 4 de julio de 1966 (RJ 5575) y 22 de enero de 1975 (RJ 8):

«Si la Administración procedió irregularmente no puede alegar su vicio en miras de anular lo concertado con la virtualidad que da el art. 1258 ... ya que en Derecho positivo no lo permiten el art. 1302 CC del mismo Código Civil, en lo concerniente a la contratación, y el art. 115.2 LPA (de 1958) ... en lo que atañe a los actos administrativos, preceptiva a que se amolda naturalmente la doctrina de estas Salas al declarar que nadie puede invocar a su favor el motivo de nulidad que haya originado...»

— STS de 10 de noviembre de 1975 (RJ 188): «... ni es aceptable que se invoque en propio beneficio un defecto contractual imputable a quien pretende obtener provecho de él...».

— STS de 20 de abril de 1976 (RJ 2345): «... nadie puede invocar en su favor el motivo de nulidad que haya originado».

— STS de 3 de noviembre de 1980 (RJ 4255): reitera, exactamente igual que la anterior que «... nadie puede invocar a su favor el motivo de nulidad que haya originado» ${ }^{25}$.

${ }^{25}$ Sobre esta sentencia, N. RoDríGUEZ MORO, «Es obligado el pago del importe de las obras realizadas en favor de un Ayuntamiento aunque el contrato se hubiere celebrado por el 
— SSTS de 25 de junio de 1981 (RJ 2483), de 8 de febrero de 1983 (RJ 550) y de 8 de marzo de 1984 (RJ 1384): califican como principio general «aquél que por similitud con la prohibición de beneficiarse de las cláusulas oscuras de un contrato a quien hubiese ocasionado la oscuridad (art. 1288 CC)» o con la otra prohibición de «alegar la persona capaz la incapacidad de aquél con quien contrato (art. 1302 del mismo cuerpo legal), impide invocar a su favor el motivo de nulidad que se haya originado por su proceder».

— STS de 29 de septiembre de 1986 (RJ 6096): «... la Administración no puede invocar sus propias infracciones para incumplir los compromisos contraídos...».

- STS de 23 de diciembre de 1986 (RJ 1567 de 1987): «... este Tribunal viene declarando ... que los defectos de forma no pueden ser alegados por la Corporación causante de los mismos».

— STS de 9 de octubre de 1987 (RJ 8321): vuelve a considerar principio general el que «impide invocar a su favor el motivo de nulidad que haya originado con su proceder» y a deducirlo por su «similitud con la prohibición de beneficiarse de las cláusulas oscuras de un contrato a quien hubiese ocasionado la oscuridad (art. 1288 CC)» o aquella otra prohibición de «alegar la persona capaz la incapacidad de aquél con quien contrató» (art. 1302 CC).

— STS de 2 de enero de 1990 (RJ 148): «... no pudiendo perjudicar los derechos de tercero las causas de anulabilidad ... de las que aparece como responsable la Administración» según del art. 115.2 LPA/58.

- STS de 31 de marzo de 1999 (RJ 3270): «En cuanto a las demás causas de nulidad que se invocan (por el propio Ayuntamiento) ... la Sala considera correcta la argumentación de la sentencia en el sentido de que conforme dispone el art. 115.2 LPA, el inadecuado proceder de la Administración no puede oponerse por ésta al tercero...».

Sin necesidad de más pruebas, puede reconocerse que la jurisprudencia contencioso-administrativa reiteradamente reconoce y procla$\mathrm{ma}$, con unas $\mathrm{u}$ otras fórmulas, pero con pequeñas variantes, que la Administración no puede alegar las ilegalidades debidas al propio comportamiento para obtener una anulación que le beneficia.

Alcalde con infracción de la normativa legal», Revista de Estudios de la Vida Local, núm. 202 (1981), pp. 737 y ss. 
DA-2002, núms. 263-264. MANUEL REBOLLO PUIG. Nemo auditur propriam turpitudinem allegans e...

\section{CRÍTICA DE LA JURISPRUDENCIA CONTENCIOSO- ADMINISTRATIVA DEL NEMO AUDITUR: NO ES CIERTO QUE NO QUEPA ALEGAR LOS VICIOS DEBIDOS A LA PROPIA CONDUCTA; EN ESPECIAL, PUEDE HACERLO LA ADMINISTRACIÓN Y ES LO CARACTERÍSTICO DE LA NULIDAD DE PLENO DERECHO}

\section{LA DOCTRINA SÓLO HA ACEPTADO ESTE PECULIAR NEMO AUDITUR COMO LIMITACIÓN PARA EL ADMINISTRADO Y RESPECTO A VICIOS DE ANULABILIDAD}

Ni siquiera con ese peculiar significado que le da la jurisprudencia contencioso-administrativa, todas las sentencias que lo citan lo hacen con alguna propiedad y acierto. Algunas de ellas, como se ha ido exponiendo, no partían de ningún incumplimiento, de ninguna ilegalidad, de ninguna omisión de cualquier requisito o formalidad. El ejemplo de la citada STS de 20 de mayo de 1992 (RJ 5095) impidiendo al recurrente alegar la inconstitucionalidad de la Orden Ministerial en la que inicialmente basó su petición es suficientemente revelador. Otras muchas se explican mejor atendiendo a la protección de la buena fe (o de la confianza legítima) o, concretamente, a la doctrina de los actos propios u otras reglas, como la de la eficacia inmediata de los actos administrativos favorables. Pero, depurado de todas estas desviaciones, excesos o citas superfluas, sigue quedando algo distinto que no se puede explicar ni siquiera como una aplicación del principio de buena fe o como una ampliación del venire contra factum proprium non valet. Es esa negación de la posibilidad de obtener provecho de las propias ilegalidades y, más concretamente, la exclusión de alegaciones de vicios invalidantes de los actos administrativos que el mismo sujeto que los alega ha originado con su comportamiento. Si este impropio y advenedizo nemo auditur añade algo nuevo de interés es precisamente esa negación de alegar como motivo de invalidez de los actos administrativos los vicios debidos a los propios incumplimientos. Así, en suma, lo que se quiere decir es que nadie puede alegar las ilegalidades debidas al propio comportamiento para obtener una anulación que le beneficia. En concreto, tratándose de relaciones jurídico-administrativas, significa que ni la Administración puede alegar las ilegalidades cometidas por ella para lograr en su beneficio la anulación de sus actos, ni lo puede hacer el administrado en la medida en que también su comportamiento puede determinar vicios de los actos administrativos.

Esta tendencia, que parece poco a poco ir reafirmándose en nuestra jurisprudencia, no es exclusiva del Derecho español. Una breve 
referencia a la doctrina argentina, que se ha ocupado explícitamente del nemo auditur en el Derecho administrativo, sirve para corroborarlo. MAIRAL escribió hace sólo unos años que «la jurisprudencia ha decidido que no rige, respecto de la Administración, la regla que impide invocar la propia torpeza ${ }^{26}$. Pero más recientemente GORDILLO presenta a esa misma jurisprudencia como parcialmente desfasada o superada: «Mientras en Derecho privado no se puede alegar la propia torpeza (nemo propriam turpitudinem allegare potest), en el Derecho administrativo antiguo (sic) la administración sí podía hacerlo, sea revocando los actos ilegítimos ... sea pidiendo en sede judicial, tanto por acción como por reconvención, la nulidad de su propio acto». Pero, dice, «cada vez se afirma más en nuestro derecho la tendencia contraria a que la administración invoque su propia torpeza, argumentando de diversas y persuasivas maneras». Con todo, en realidad, del panorama que ofrece puede deducirse que, más que una verdadera prohibición de alegar las propias torpezas, lo único que hay es una prudente aplicación de los principios de seguridad jurídica y buena $\mathrm{fe}^{27}$.

La doctrina administrativa española, en general, no llega a proclamar, al menos no con tanta amplitud y rotundidad, tal supuesto principio de que nadie puede alegar los vicios de nulidad de los actos administrativos debidos a la propia actuación ilegal. Frecuentemente no es aludido de ninguna forma. En algún caso, los autores se limitan a dar noticia de esta jurisprudencia sin cuestionarla ${ }^{28}$. En otros, aparece

${ }^{26}$ H.A. MAIRAL, La doctrina de los propios actos y la Administración pública, Buenos Aires, 1988, p. 78, donde cita jurisprudencia y doctrina en apoyo de su afirmación. Después, en p. 102, reitera: «... la Administración puede plantear la nulidad de los actos administrativos firmes que ha dictado y que considere viciados en su legitimidad, sin que quepa oponerle el factum proprium ni, ha dicho la jurisprudencia, la regla que prohíbe invocar la propia torpeza».

${ }_{27}$ A. Gordillo, Tratado de Derecho administrativo, tomo 3, El acto administrativo, $5^{\mathrm{a}}$ ed., Buenos Aires, pp. XX-7 a 9. Además, luego parece reconocer que sólo hay «síntomas que parecen preanunciar el cambio formal», que sólo hay «el caldo de cultivo para un cambio...». Al parecer, una incipiente tendencia similar puede observarse en el Derecho inglés, tendencia en la que juega un cierto papel el nemo auditur. Véase D. SARMIENTO RAMíREZ-EscudE$\mathrm{RO}$, El principio de confianza legítima en el Derecho inglés: la evolución que continúa», REDA, núm. 114 (2002), pp. 249 a 251.

${ }^{28}$ Así, en concreto, F. SAINZ MORENO, en su precursor y excelente estudio «La buena fe en las relaciones de la Administración con los administrados», RAP, núm. 89 (1979), p. 313, que presenta a esta aplicación jurisprudencial del allegans propriam turpitudinem non auditur como una concreción del principio de buena fe. Y en la misma línea F. CASTILlo BlanCO, La protección de confianza en Derecho Administrativo, Madrid, 1998, p. 259. Véase también L. MORELL OCAÑA, "La lealtad y otros componentes de la ética institucional de la Administración», REDA, núm. 114 (2002), p. 193. Más atención recibe en J.L. PIÑAR MAÑAS (dir), La reforma del procedimiento administrativo. Comentarios a la Ley 4/1999, de 13 de enero, Madrid, pp. 292-293, donde R. AguILAR Ros afirma que el nuevo art. 110.3 LRJPAC «no es sino la expresión del principio nemo auditur propiam turpitudinem allegans ... principio invocado en numerosas ocasiones por la jurisprudencia del Tribunal Supremo...». 
DA-2002, núms. 263-264. MANUEL REBOLLO PUIG. Nemo auditur propriam turpitudinem allegans e...

sólo como un límite para el administrado, sin referencia alguna a la Administración. En esta línea, GARCÍA DE ENTERRía y FERNÁNDEZ RODRíGUEZ, al analizar los vicios de la voluntad declarada en los actos administrativos, recuerdan que «las personas que hayan determinado o inducido al error, la violencia o la intimidación, el dolo, no podrán invocar el vicio por ellas causado o al que ellas han contribuido, ni tampoco intentar beneficiarse del acto producido» lo que precisamente anudan al «principio general de Derecho, proclamado por nuestra jurisprudencia, allegans propriam turpitudinem non auditur, de la propia torpeza no pueden obtenerse beneficios, principio que recoge parcialmente el art. 115.2», ahora, 110.3 de la LRJPAC ${ }^{29}$. Nótese, por tanto, que no deducen de aquí ningún límite para la Administración: sólo para el administrado y, en realidad, sólo respecto a determinados vicios de manera prácticamente idéntica a lo dispuesto en el artículo 1302 CC, al que no citan. Junto a ello, otro límite también para el administrado: si es la Administración la que pretende anular el acto administrativo obtenido con violencia o intimidación o dolo por el administrado o por error inducido por éste -todo lo cual relacionan con la obrepción y subrepción-, no habrá derecho a indemnización, tal y como refleja para un supuesto concreto la legislación urbanística (ahora art. 44.2 in fine de la Ley 6/1988, de 13 de abril, sobre Régimen del Suelo y Valoraciones); y, menos aún, cabe aceptar que el administrado que empleó esos medios determinantes de la invalidez pueda alegar, frente a la pretensión anulatoria de la Administración, la confianza legítima ${ }^{30}$.

\section{ESTE NEMO AUDITUR NO TIENE FUNDAMENTO POSITIVO Y, POR EL CONTRARIO, CHOCA CON LOS CARACTERES DE LA NULIDAD DE PLENO DERECHO Y CON EL RÉGIMEN DE REVISIÓN DE OFICIO}

Más allá de esta limitación a las alegaciones del particular de ciertos vicios del acto administrativo debidos a su comportamiento no se

${ }^{29}$ E. García de EnTERría y T.R. FernándeZ, Curso de Derecho administrativo, tomo I, $10^{\mathrm{a}}$ ed., Madrid, 2000, p. 553. Debe observarse, no obstante, que el art. 110.3 LRJPAC se refiere a vicios de anulabilidad mientras que algunos de los que citan estos autores podrán considerarse incluidos en la causa de nulidad de pleno derecho del art. 62.1.d) de la LRJPAC.

${ }^{30}$ A este respecto J. GARCÍA LuENGO, El principio de protección de la confianza legítima, Madrid, 2002, p. 353, habla precisamente del «principio según el cual nadie puede beneficiarse de su propia torpeza». Sobre todo, cuando en págs. 360 y ss., estudia las circunstancias que excluyen la protección de la confianza en el Derecho alemán, se pone de relieve la relación con nuestro objeto. Explica que se excluye la protección de la confianza cuando el destinatario ha obtenido dolosamente el acto, con fraude, intimidación o cohecho, así como cuando ha suministrado información incorrecta o incompleta. Tras ello afirma «la evidente conexión ... con el principio reiteradamente proclamado en nuestro Ordenamiento en general y en el Derecho Administrativo en particular, allegans propriam turpitudinem non auditur o, dicho en otras palabras, que nadie puede beneficiarse de su propia torpeza» (p. 384). 
puede afirmar o confirmar este peculiar nemo auditur lo que, sin embargo, no excluye que todas las consecuencias a que llega su aplicación sean equivocadas. Podría ocurrir que algunas sean correctas pero que realmente no se basen en la prohibición de alegar la propia ilegalidad sino en otros principios y reglas. Pero si, en efecto, son estos otros principios y reglas los que realmente justifican algunas de las soluciones a las que se ha llegado con aplicación del nemo auditur, importa mucho deshacer su falso fundamento, no ya sólo porque «la sentencia que falla bien y razona mal no satisface los ideales de la justicia», sino porque, al proclamar una supuesta regla general que prohíbe conseguir la nulidad de un acto administrativo alegando la propia ilegalidad, se llega indefectiblemente a otras muchas conclusiones equivocadas, excesivas y claramente contrarias a lo que establece el Derecho. Si el TS no ha llegado a las conclusiones equivocadas y flagrantemente injustas a que conduciría la aplicación estricta de esta jurisprudencia es porque no la aplica normalmente -al contrario, en infinidad de supuestos se aceptan nulidades basadas en vicios originados por el mismo que los invoca-, sino sólo en algunos casos en que ve razonable impedir que prosperen las alegaciones de nulidad debidas al comportamiento del mismo que la invoca. Por mucho que se presente como una jurisprudencia basada en un supuesto principio general, es, en realidad, una jurisprudencia casuista que, en la mejor de las hipótesis, busca y logra la justicia del caso concreto y que, no encontrando mejores argumentos o huyendo de explicaciones más difíciles o embarazosas, echa mano de este tópico nemo auditur.

Lo cierto es que no sólo no se encuentra ningún fundamento sólido a este peculiar nemo auditur, sino que choca frontalmente con la legalidad y con algunas instituciones capitales y perfectamente asentadas. Por lo pronto, sobre todo, con el significado y régimen jurídico de la nulidad de pleno derecho. También, más concretamente, con la revisión de oficio de los actos nulos y con el recurso de lesividad contra los actos anulables.

\subsection{Los supuestos apoyos deducidos del Código Civil: en particular, el artículo 1302 sólo se refiere a casos de anulabilidad, no de nulidad de pleno derecho, nulidad ante la que ni siquiera se considera aplicable la doctrina de los actos propios}

Desde luego, el supuesto fundamento en el artículo 1288 CC, que es uno de los más reiteradamente invocados, no resiste la crítica. La regla según la cual «la interpretación de las cláusulas oscuras de un contrato no deberá favorecer a la parte que hubiese ocasionado la oscuridad» puede, en efecto, aplicarse en Derecho administrativo, aun- 
DA-2002, núms. 263-264. MANUEL REBOLLO PUIG. Nemo auditur propriam turpitudinem allegans e...

que con matizaciones ${ }^{31}$. Pero resulta casi inimaginable cómo podría deducirse de ello que nadie puede alegar los vicios invalidantes que él mismo originó. Tanto que casi es difícil combatir una conclusión tan poco razonable. Bástenos decir que, salvo error u omisión, nadie ha deducido del artículo 1288 CC que, en Derecho civil, las partes no puedan alegar los vicios que hayan originado. Algo parecido puede decirse de la insólita alusión al artículo 1270 CC, que aparece en alguna ocasión como fundamento de nuestra regla y en el que es difícil encontrar relación con ella salvo por su exclusión del dolo empleado por las dos partes como determinante de invalidez, dolo doble que ni siquiera se daba en ninguno de los supuestos considerados. Por lo que se refiere al supuesto apoyo en los artículos 1305 y 1306 CC, que ocasionalmente aparece en alguna de las sentencias como fundamento de la regla, casi no hace falta explicar a estas alturas que eso no es más que un juego de palabras basado en la homonimia inventada previamente: en efecto, los artículos 1305 y 1306 CC consagran la regla nemo auditur propriam turpitudinem allegans con el significado que ya explicábamos antes que nada tiene que ver con el que le da la jurisprudencia contencioso-administrativa, hasta el punto de que esos artículos ni siquiera impiden alegar el vicio de nulidad consistente en la inmoralidad o ilicitud cualificada de la causa.

Más atinada es la referencia reiterada en las sentencias recogidas al artículo 1302 CC que, por ello, merece mayor detenimiento. Tras establecer la regla general de que cualquiera de las partes de un contrato puede ejercitar la acción de nulidad, establece: «Las personas capaces no podrán, sin embargo, alegar la incapacidad de aquellos con quienes contrataron; ni los que causaron la intimidación o violencia, o emplearon el dolo o produjeron el error, podrán fundar su acción en estos vicios del contrato». Pese a alguna similitud y a un cierto campo común con la prohibición de que se aleguen los vicios invalidantes debidos a la propia conducta, hay diferencias notables por las cuales no se ha deducido de este artículo una regla similar en el Derecho civil. Muy por el contrario, según jurisprudencia y doctrina absolutamente dominante, el artículo 1302 CC es sólo una pieza capital en el régimen jurídico de la anulabilidad de los contratos e, incluso así, necesitada de alguna matización porque no se trata sólo de que quienes emplearon esos medios no puedan invocarlos sino más exactamente que sólo los que sufrieron el dolo, la violencia, la intimidación... pueden hacer valer la anulabilidad basada en esos vicios. Pero, en cualquier caso, cuando se trata de nulidad de pleno derecho se afirma rotundamente que la puede alegar cualquier interesado incluido, desde

${ }^{31}$ Véase E. RIVERO YSERN, La interpretación del contrato administrativo, Sevilla, 1997, pp. 116 a 119. 
luego, el mismo causante del vicio. Esto es casi un lugar común repetido una y mil veces. Y se aclara expresamente, incluso, que a ello no se opone la doctrina de los actos propios. Es especialmente clara la exposición de DELGADO ECHEVERRÍA precisamente al comentar el artículo 1302 CC y poniendo de relieve que lo que este artículo consagra no es de ninguna forma aplicable a los vicios de nulidad de pleno derecho:

«La nulidad absoluta, aunque no genera una acción pública, puede hacerla valer cualquier particular que muestre un interés legítimo (...) En primer lugar, por tanto, puede hacerla valer cada uno de los contratantes (...), aun cuando haya causado voluntariamente la nulidad. La consideración que de este modo se fomenta la denuncia de la ilegalidad (...) triunfa sobre el principio de que nadie puede ir contra sus actos propios (éstos, para que actúe el principio, han de ser válidos, suele decir la jurisprudencia)» ${ }^{32}$.

${ }^{32}$ En Comentarios al Código Civil y Compilaciones Forales, op. cit., XVII, 2º pp. 387-388. Cita después jurisprudencia civil que prueba definitivamente que, según el TS, concordemente con la doctrina, los vicios de nulidad los puede invocar el que los originó sin que nada, incluida la teoría de los propios actos, se oponga a ello. A las sentencias que cita pueden añadirse otras posteriores como la del TS de 3 de marzo de 1995: «El tipo de invalidez de que adolece la donación con defecto de forma es el de la nulidad absoluta...»; por tanto, «no puede mantenerse que la doctrina de los actos propios permita amparar al donatario de donación nula frente al donante que la ratifica o cumple de modo voluntario y después acciona pidiendo la nulidad...». Véase también L. DíEZ-PICAZO PONCE DE LEÓN, La doctrina de los propios actos, op. cit., pp 201 y ss., sobre la aplicación de tal doctrina a supuestos de anulabilidad, pero no de nulidad. Sin embargo, su exposición a este respecto no es del todo clara. De una parte, en p. 201, afirma que «se puede venir contra los propios actos realizados contraviniendo la ley y siempre que el acto sea absolutamente nulo». De otra, en la página siguiente dice: «Se viene lícitamente contra un factum proprium cuando se pretende la declaración de ineficacia de un negocio irregular, cualquiera que sea el tipo de ineficacia con que el ordenamiento jurídico sancione aquella irregularidad».

Aunque críticamente, M. PASQUAU LiaÑo, Nulidad y anulabilidad del contrato, Madrid, 1997, sintetiza con especial acierto esta jurisprudencia consolidada: en p. 131 afirma que si el contrato es nulo «cualquiera puede pedir la nulidad, incluso quien la ha causado. Ningún límite se impone a la legitimación para instarla, y la difusa doctrina de los actos propios nada tiene que hacer frente a la contundencia de las consecuencias de la nulidad». En p. 136 insiste: «El carácter absoluto de la nulidad, con el corolario de una legitimación abierta a todo interesado, propicia acciones de nulidad interpuestas por quien ha creado conscientemente o participado en el vicio invalidatorio del contrato; contratos con causa ilícita en los que una de las partes utiliza la nulidad protectora de la ley o de las buenas costumbres para desligarse de compromisos firmemente asumidos; contratos con deficiencias formales que son invocadas por quien los otorgó para recuperar bienes cuando cambiaron las circunstancias...». En p. 145 dice: «nulidad y vinculación por los actos propios son cosas incompatibles». En pp. 154-155 explica los supuestos fundamentos de esta construcción: «Si un contrato es nulo (por estar afectado de una causa de nulidad), es nulo para todos (...) Al ser una cualidad del mismo, el juicio de validez/nulidad es un juicio objetivo, un juicio de comprobación que sólo mira al contrato, y no a quien interpone la demanda de nulidad. De ahí que, necesariamente, si el contrato adolece de una causa de nulidad, cualquiera que interponga una demanda pidiendo que así se declare, vencerá en juicio; bastará, entonces, que esté interesado en una tal declaración...». 
DA-2002, núms. 263-264. MANUEL REBOLLO PUIG. Nemo auditur propriam turpitudinem allegans e...

Por tanto, salvo que se rompa con una arraigada doctrina, el artículo 1302 CC no puede invocarse como justificación de que no se puedan alegar los vicios de nulidad de pleno derecho generados por el mismo que los alega porque, lejos de ello, es presentado con «un carácter excepcional, al señalar los únicos casos en los que la nulidad no queda abierta a ambas partes contractuales, siendo todos ellos de anulabilidad ${ }^{33}$.

\subsection{El artículo 110.3 LRJPAC tampoco justifica una regla con la amplitud del nemo auditur aplicado por los Tribunales}

Pero, sin ningún género de dudas, el precepto más insistentemente citado como fundamento de que nadie -y, en especial, la Administración- puede invocar los vicios de nulidad que él mismo ha originado es el artículo 115.2 de la LPA/58 que, como ya explicamos, se contenía en idénticos términos en el artículo 115.2 de la Ley 30/1992 y con mínimas modificaciones, tras la reforma operada por la Ley 4/1999, en el actual artículo 110.3 LRJPAC.

Algunas sentencias, como se ha visto, afirman que ese precepto es la formulación misma del principio o que este principio está expresamente incorporado al Derecho positivo por él; otras, más tímidamente, sólo dicen que el principio se deduce de él o que éste es una concreción o manifestación parcial de tal principio. Pero no me parece de ninguna forma que el artículo 110.3 LRJPAC -como tampoco, claro está, el anterior artículo 115.2 LPA/1958- recoja o exprese el tan traído y llevado principio. No digo ya que no tenga nada que ver con las notificaciones erróneas ni con la imposibilidad de alegar la inconstitu-

${ }^{33}$ M. Pasquau Liaño, Nulidad y anulabilidad..., op. cit., p. 224. Pero debo reconocer que el mismo PASQUAU, apartándose conscientemente de esa posición consolidada y dominante, afirma después, en p. 232, que «el art. 1302, leído sin prejuicios, permite identificar en él una ratio que es perfectamente generalizable fuera de los casos expresamente mencionados en él (...) Liberado de la lectura reduccionista que lo quiere referir exclusivamente a los casos de anulabilidad, el art. 1302 no es más que expresión de claros principios generales, como el que prohíbe ir contra los propios actos y el que prohíbe el abuso de derecho». Y ya en esta línea llega a afirmar, en contra de la doctrina y jurisprudencia civil y casi como la jurisprudencia contencioso-administrativa que analizamos, lo siguiente: «no puede invocar la nulidad la parte contractual que voluntariamente ha creado la causa de nulidad (art. 1306 )», o sea, con apoyo en el mismo precepto del nemo auditur. Todas estas afirmaciones se inscriben en una construcción mucho más amplia y ambiciosa con la que PASQUAU pretende montar las bases para una reconsideración del régimen jurídico de la nulidad y, entre otras cosas, articular una categoría de nulidades de pleno derecho relativas. Sobre ello volveremos luego brevemente. También he de confesar que L. DíEZ-PICAZO PONCE DE LEÓN, La doctrina de los propios actos, op.cit., p. 203, sí establece una relación directa entre este art. 1302 CC y el nemo auditur, aunque me parece que se trata de un error que no se refleja de ninguna forma en su obra posterior. 
cionalidad de una norma en la que previamente se basó una petición... y otras aplicaciones ya completamente desviadas y antes criticadas y que, en realidad, ni siquiera encajan con el supuesto principio. Digo ahora que ese precepto no plasma ni refleja el principio de que nadie puede invocar los vicios de nulidad que haya originado ${ }^{34}$. Muy lejos de ello, el precepto sólo se refiere a los motivos de los recursos administrativos (porque está contenido en el capítulo dedicado a los recursos administrativos y, concretamente, en el artículo dedicado a la interposición de los recursos administrativos) y únicamente se refiere a «los vicios y defectos que hagan anulable un acto», no nulo de pleno derecho. Así las cosas, no hay inconveniente en extender la misma regla a los recursos contencioso-administrativos que interpongan los mismos particulares. Pero la extensión de la regla no puede ir más allá. Ni se puede extender a los vicios de nulidad de pleno derecho ${ }^{35}$ alegados por los particulares que los hayan originado; ni, y esto es lo más importante, cabe extender la limitación del artículo 110.3 LRJPAC a la propia Administración que hace valer cualquier vicio invalidante al margen de un recurso, sobre todo si es un vicio de nulidad de pleno derecho.

Hay muchísimas razones para negar que del artículo 110.3 LRJPAC se pueda deducir la prohibición de alegar los vicios causados por uno mismo con la amplitud con que lo acepta la jurisprudencia contencioso-administrativa. Entre ellas que este precepto aparece claramente como una excepción a la regla general que se contiene ahora en el artículo 107.1 LRJPAC según el cual los recursos administrativos se pueden «fundar en cualquiera de los motivos de nulidad o anulabilidad previstos en los artículos 62 y 63 de esta Ley». Además, cuando la LRJPAC habla de «anulable» en el artículo 110.3 lo hace, como en toda la Ley, con plena conciencia, propiedad e intención, igual que antes lo hacía la LPA/58, y no hay ninguna razón para pensar que se equivoque al emplear ese término o que quisiera referirse indistintamente a nulidad y a anulabilidad. Todo lo contrario: el mismo régi-

\footnotetext{
${ }^{34}$ Y ni siquiera es una consecuencia de la buena fe. En contra, J. GONZÁLEZ PÉREZ y F. GónzÁlez NaVArro, Comentarios a la Ley de Régimen Jurídico de las Administraciones Públicas y del Procedimiento Administrativo Común, Madrid, 1997, II, p. 1764, afirman que «puede considerarse esta limitación una aplicación del principio de buena fe». No creo que sea así sino que hay sólo una consecuencia del régimen típico de la anulabilidad.

${ }^{35} \mathrm{Si}$ del art. $1302 \mathrm{CC}$ se puede llegar a pensar que si se identifica con la anulabilidad es sólo porque se lee con los prejuicios de la doctrina pero que no es imposible, liberado de tales prejuicios, aplicar el principio que late en él a la nulidad de pleno derecho, según dice PASQUAU (véase la anterior nota 33), es imposible afirmar lo mismo del art. 110.3 LRJPAC: se refiere sólo y exclusivamente a vicios que hagan «anulable» al acto. A lo sumo cabe decir que la LRJPAC está directamente influida por la teoría de las nulidades construida por la doctrina civilista según la cual sólo la anulabilidad tiene restringido el ámbito de los sujetos legitimados para alegarla.
} 
DA-2002, núms. 263-264. MANUEL REBOLLO PUIG. Nemo auditur propriam turpitudinem allegans e...

men y significado de la nulidad de pleno derecho de los actos y de los contratos administrativos, según es generalmente explicado, lleva indefectiblemente a concluir que, en efecto, cualquier interesado puede invocar los vicios de nulidad radical, aunque sea él mismo el que los haya originado ${ }^{36}$. En realidad, el artículo 110.3 LRJPAC es casi una perfecta plasmación del régimen clásico de la anulabilidad. Este apartado, como su predecesor de la Ley de 1958, es el equivalente al artículo 1302 CC, pero desprovisto ya de su casuismo y pasado por el tamiz de la teoría de las nulidades elaborada por la doctrina civilista y adaptada al Derecho administrativo. Por eso habla con toda precisión de anulabilidad y es completamente contrario a su letra, a su espíritu y a su rigor conceptual pretender deducir de ahí una regla válida también para los vicios de nulidad de pleno derecho ${ }^{37}$.

\subsection{El régimen de revisión de oficio choca con este nemo auditur}

Por otra parte, aplicar a la Administración esta limitación de que nadie puede alegar los vicios invalidantes que hubiere causado choca frontalmente con el régimen de la revisión de oficio de los actos nulos (art. 102 LRJPAC; y, hasta 1999, de los actos anulables: art. 103 de la LRJPAC en su redacción originaria) y con el recurso de lesividad contra los actos anulables (art. 103 LRJPAC). El Consejo de Estado lo ha destacado con gran acierto y claridad:

«Estas invocaciones de nulidad no podrían yugularse de inmediato ... por el precepto según el cual 'los vicios y defectos que hagan anulable el acto no podrán ser alegados por los causantes de

\footnotetext{
${ }^{36}$ En realidad, las cosas son incluso más radicales puesto que, como es sabido, siempre se afirma, que la nulidad de pleno derecho de los actos administrativos debe ser declarada incluso de oficio por el Tribunal, aunque nadie la pidiera y aunque el recurso haya sido interpuesto por persona no legitimada. Por todos, L. Cosculluela MonTANER, Manual de Derecho administrativo, op. cit., p. 348, y E. GARcÍA DE ENTERría y T.R. FERnándeZ, Curso..., I, op. cit., pp. 612-613.

${ }^{37} \mathrm{O}$ sea, que el art. 110.3 LRJPAC (antes 115.2) expresa muy claramente y con acierto lo que quiere decir y no hay base alguna para hacerle decir más de lo que dice. Por tanto, si acaso, podrá afirmarse que consagra el nemo auditur respecto del administrado recurrente y sólo en cuanto a ciertos vicios, como, según vimos, hacían GARCÍA DE ENTERRÍA y FERNÁNDEZ RODRÍGUEZ. A lo sumo, llevándolo más lejos de lo que lo hacían estos autores (que sólo se referían a los casos de dolo, intimidación, error o violencia), deben incluirse todos los vicios de anulabilidad, puesto que el art. 110.3 LRJPAC, a diferencia del art. 1302 CC, se refiere genéricamente a todos ellos. Pero, como ha quedado claro, el TS aplica esta prohibición de alegar las propias ilegalidades como motivo de anulación a la Administración y a todos los vicios, incluidos los de nulidad de pleno derecho. En realidad, el TS, al aplicar esta regla, ni siquiera distingue y ni si plantea si el vicio es de nulidad o anulabilidad. Pero, en la mayoría de los casos, se trataba de nulidad de pleno derecho (compromiso de gastos sin partida presupuestaria, supuestos de incompetencia manifiesta, etc.).
} 
los mismos' (art. 115.2 LPA/58). Esta norma aparece recogida a propósito de los recursos de alzada y reposición ... y directamente apuntan a que el recurrente no puede alegar vicios o defectos por él causados. La extensión de este mandato y limitación a la Administración implicaría suscitar una cuasieliminación de la revisión de oficio de los actos de la propia Administración, ya que, por supuesto, la Administración los ha causado... Esto quiere decir que la invocación al caso del conocido principio de Derecho de que nemo auditur propriam turpitudinem allegans debe hacerse con la circunspección que exige el respeto a la Ley que consagra ... remedios y procesos instrumentales de retorno a su mantenimiento que no pueden ser cegados» ${ }^{38}$.

Claro está, en efecto, que en la inmensa mayoría de los casos los vicios de los actos administrativos son exclusivamente debidos a la propia Administración y que si la Administración puede revisar de oficio sus actos nulos e impugnar ante la jurisdicción contencioso-administrativa sus actos anulables es porque puede alegar los motivos de invalidez que ella misma originó ${ }^{39}$. Y en el caso de la nulidad de pleno derecho, no sólo puede, sino que debe hacerlo, como es ya hoy unánimemente admitido y plasma incluso literalmente la actual redacción del artículo 102.1 LRJPAC al decir «declarará» y no simplemente «podrá declarar». Negar esto supondría desactivar todo el sistema de los artículos 102 y 103 LRJPAC y además, en realidad, dejar que se consumen sin remedio las ilegalidades más perjudiciales para los intereses generales a los que debe servir la Administración (art. 103.1 CE) ${ }^{40}$.

\footnotetext{
${ }^{38}$ Dictamen 53.437, de 6 de julio de 1989; Recopilación de doctrina legal, núm. 54.

${ }^{39}$ Valen para esto los mismos argumentos que empleó GARCÍA DE ENTERRÍA, «La doctrina de los actos propios y el sistema de lesividad», $R A P, 20,1956$, sobre todo pp. 73 a 75, para poner de manifiesto que la misma existencia del recurso de lesividad desvanece la eficacia de la vinculación de los actos propios.

${ }^{40}$ No es ésta una afirmación retórica y vacía de contenido. Ya se ha dicho que tampoco es cierto en Derecho civil que los particulares no puedan alegar las causas de nulidad absoluta que hayan originado; y que en Derecho administrativo tampoco hay una regla que prohíba a los administrados alegar los vicios de nulidad radical de los actos administrativos, aunque ellos los hubieran originado. Por tanto, tampoco cabe afirmarlo sin más de la Administración. Pero aunque fuera cierto para los particulares, no tendría que ser cierto para la Administración. Hay razones que justificarían una diferencia radical. Podrá aceptarse, tal vez, que un particular no consiga una nulidad que le interesa como una especie de sanción por su conducta ilegal anterior. Pero eso no tiene ningún sentido para la Administración: sería absurdo decir que la Administración no puede conseguir una nulidad que conviene a los intereses generales (la de una autorización ilegal que permite un daño al medio ambiente o a la salud pública, por ejemplo; la de un acto que supone un ilegal compromiso de gasto que endeuda inútilmente y por años a un Municipio ...) porque fue ella misma la que cometió la ilegalidad; eso sería dejar injustamente desprotegidos a los intereses generales y a los ciudadanos por unas culpas de unas autoridades y funcionarios que actuaron ilegalmente; sería como sancionar a todos por las ilegalidades que cometieron concretas personas.
} 
DA-2002, núms. 263-264. MANUEL REBOLLO PUIG. Nemo auditur propriam turpitudinem allegans e...

En conclusión, como ya adelantábamos, este nemo auditur inventado por la jurisprudencia contencioso-administrativa, no sólo no tiene fundamento sino que es contrario al Derecho positivo, sobre todo al régimen jurídico-administrativo de la nulidad de pleno derecho, de la revisión de oficio y del recurso de lesividad.

\section{SOLUCIONES SIMILARES A LAS QUE SE LLEGA CON EL NEMO AUDITUR PUEDEN Y DEBEN LOGRARSE POR OTRAS VÍAS: EN ESPECIAL, LA EQUIDAD COMO INSTRUMENTO PARA MODERAR LOS EXCESOS DE LA NULIDAD DE PLENO DERECHO}

Dicho lo anterior, nuestra misión puede darse por terminada y sólo nos queda decir, en consecuencia, que debe abandonarse esa jurisprudencia contencioso-administrativa sobre el nemo auditur: ni el aforismo latino significa que nadie pueda alegar sus propias ilegalidades para conseguir la nulidad de un acto, ni es verdad que nadie pueda alegar sus propias ilegalidades para conseguir la nulidad de los actos administrativos; en particular, la Administración pública sí puede alegar sus ilegalidades como vicios invalidantes, sobre todo, si determinan la nulidad de pleno derecho de sus actos: afortunadamente es así en nuestro Derecho y debe seguir siendo así como regla general . Ese nemo auditur es falso, y se basa en una suma de errores y en un cúmulo de, si se me permite la expresión, torpezas.

Pero todavía conviene añadir que lo que de justicia y acierto tiene esta jurisprudencia podía y debía haberse conseguido por otras vías: respetando el régimen positivo de la invalidez, sobre todo de la nulidad de pleno derecho, pero moderándolo drásticamente con una aplicación más amplia del artículo $106 \mathrm{LRJPAC}^{41}$. Este artículo puede suministrar la vía correcta para llegar a las soluciones aceptables en las que la jurisprudencia se ha servido de su peculiar nemo auditur. Para extraer del art. 106 LRJPAC todas sus virtualidades, sin que en absoluto se traicione su sentido general, debe aceptarse que se aplique, no sólo como límite a las facultades de revisión de la Administración, que es como formalmente aparece en la LRJPAC, sino también, al menos,

\footnotetext{
${ }^{41}$ En su caso, también se pueden dulcificar las consecuencias excesivas e injustas de la nulidad completando su régimen con otras instituciones como la responsabilidad patrimonial de la Administración causante de los vicios de invalidez y, por tanto, de los daños que ello genere, o como la actio de in rem verso, pues el enriquecimiento eventualmente obtenido será más patentemente injusto si tiene su origen en las ilegalidades del enriquecido. Véase mi monografía El enriquecimiento injusto de la Administración..., op. cit., pp. 365-366, y L. CosCULluela Montaner, Manual de Derecho administrativo, op.cit., p. 439. Pero no es esto, que nos llevaría demasiado lejos, lo que nos importa ahora.
} 
como límite a la posibilidad de que la Administración alegue, en los recursos contencioso-administrativos en que aparece como demandada, la excepción de invalidez de sus actos y contratos debida a sus propias ilegalidades ${ }^{42}$.

El artículo 106 LRJPAC llama a la buena fe y ello debe completarse con la actual proclamación de la confianza legítima (art. 3.1 in fine de la LRJPAC). Todo ello mitiga en favor de la seguridad jurídica el régimen de la invalidez y sobre todo el más severo de la nulidad de pleno derecho. En alguna medida eso podría ser suficiente para llegar a las mismas soluciones que el TS alcanza por la incorrecta vía del nemo auditur o a otras próximas o similares y tal vez más ajustadas. En este mismo número monográfico hay estudios específicos sobre la buena fe y la confianza legítima por lo que basta aquí con esta alusión. A lo sumo, conviene recordar que una de las manifestaciones o concreciones del principio de buena fe, siempre admitida como tal, es la prohibición de abuso de la nulidad por motivos formales ${ }^{43}$, que podría ser suficiente para corregir gran parte de los excesos que la jurisprudencia analizada pretende eliminar con el nemo auditur.

Pero creo que la buena fe y la confianza legítima no son suficientes por sí solas para justificar todas las soluciones razonables a las que llega la jurisprudencia del nemo auditur. Hay algo de razón y de justicia en esa jurisprudencia que no se consigue del todo con la buena fe y la confianza legítima (máxime teniendo en cuenta que la doctrina de los actos propios - concreción de la buena fe-se desvanece ante los supuestos de nulidad de pleno derecho, según la doctrina dominante, como ya recordamos). Algo, sin embargo, que también está en el artículo 106 LRJPAC y a lo que se ha prestado mucha menos atención que a la buena fe y la confianza legítima, y que ya no se basa en el valor de la seguridad jurídica sino en otro muy distinto: la equidad. Según el artículo 106 LRJPAC tampoco pueden ser ejercitadas las facultades de revisión de actos inválidos cuando, por cualesquiera circunstancias (el precepto dice «cuando por prescripción de acciones, por el tiempo transcurrido o por otras circunstancias») «su ejercicio resulte contrario a la equidad» ${ }^{44}$. Así que el régimen estricto de la invalidez se atempera, por un lado, en favor de la seguridad jurídica y, por otro, en favor de la equidad. Y cabe

${ }^{42}$ Así lo he defendido ya en El enriquecimiento..., op. cit, pp. 395 y ss. Véase también J. García Luengo, El principio de protección..., op. cit., pp. 347 y 412 y ss., que señala, no obstante, que esa posibilidad de aplicación del art. 106 LRJPAC a los recursos administrativos debe limitarse por la protección a terceros perjudicados por actos administrativos.

${ }^{43}$ Por todos, L. Dí́zZ-PicAzo, en el prólogo al libro de F. WIEACKER, El principio general de la buena fe, Madrid, 1982, p. 22. En la doctrina administrativa, véase J. GONZÁLEZ PÉREZ, El principio general de la buena fe en el Derecho Administrativo, op. cit., pp. 76-77, y F. SAINZ MORENO, La buena fe en las relaciones de la Administración..., op. cit., p. 313.

${ }^{44}$ Véase F. Castillo Blanco, La protección..., op. cit., pp. 279 y ss. 
DA-2002, núms. 263-264. MANUEL REBOLLO PUIG. Nemo auditur propriam turpitudinem allegans e...

pensar que los Tribunales, en el fondo, han aplicado esta limitación a los casos en que la nulidad se pretende hacer valer en un contenciosoadministrativo, ya sea por el demandante ya sea, sobre todo, por la Administración demandada causante de la invalidez alegada por ella misma. Sólo que lo han hecho, en vez de invocando sin más la equidad, disfrazándola con ese nemo auditur del que hemos dado cuenta.

Pero con esto no queremos decir, a la postre, que el nemo auditur esté realmente justificado como un principio general que se deduce de la equidad. Nada de eso. La equidad es la justicia del caso concreto, una válvula de escape cuando la fórmula de la ley es muy rígida y su aplicación mecánica y ciega a todos los casos, incluso a aquellos en que no pensó el legislador, está reñida con lo que parece razonable. La equidad no se deja encerrar en reglas ni principios so pena de dejar de ser lo que es. Por definición, las soluciones de equidad no son susceptibles de organizarse en un cuerpo de principios que determine las soluciones futuras, pues dependen de las circunstancias particulares de cada caso considerado individualmente. Así que, como hemos dicho, no cabe de ninguna forma establecer una regla de equidad en virtud de la cual nadie pueda alegar los vicios de nulidad que haya originado y menos aún cabe predicar eso de la Administración pública respecto de sus actos y contratos viciados por su culpa. No nos retractamos de tales afirmaciones lo más mínimo. Pero, a veces, en algunos casos concretos, más bien excepcionales, es contrario a la equidad permitir que se consiga la nulidad invocando la propia conducta ilegal. Naturalmente no procede intentar enumerar con carácter general tales casos; ni, menos aun, deducir una regla o un principio general.

El artículo 3.2 CC permite que las resoluciones de los Tribunales descansen «de manera exclusiva en ella (la equidad) cuando la ley expresamente lo permita». No se encontrará mejor campo para basar exclusivamente las decisiones en la equidad que en la anulación de actos administrativos pues expresamente permite el artículo 106 LRJPAC que no se revisen cuando resulte contrario a la equidad. Así que los Tribunales podrían directamente haber fundado sus soluciones en la equidad en vez de en el falso y excesivo fundamento del nemo auditur.

Pero es que, además, según creo, el régimen de la nulidad de pleno derecho ofrece un terreno especialmente necesitado de las moderaciones de la equidad. Ésta siempre encuentra su mejor campo cuando el Derecho es muy rígido y no presenta matizaciones o posibilidad de adaptación a la diversidad de supuestos. Y esto es lo que sucede con el régimen de la nulidad de pleno derecho y su inexorable consecuencia de estar abierta su invocación a cualquier interesado, o sea, a cualquiera que tenga interés en conseguir la anulación, a todo el que obtenga un provecho con la anulación. Tan unidas están las dos nociones que se consideran sinónimas las expresiones nulidad de pleno derecho y 
nulidad absoluta, es decir, nulidad para todos, nulidad que puede alegar cualquiera que obtenga provecho con ella, aunque no tengan ningún interés en que se respete la norma cuya vulneración determina el vicio. Ello, sumado a la progresiva ampliación de los casos de nulidad de pleno derecho de los actos administrativos y a un concepto de interés legítimo desvinculado absolutamente del interés protegido por la norma violada, hace que, en algunos casos, se llegue a soluciones poco o nada equitativas que, entre otras cosas, acaban por premiar el comportamiento ilegal y hasta por traicionar la finalidad de la norma viola$\mathrm{da}^{45}$. Ante ello, la equidad, a la que sabiamente llama el artículo 106 LRJPAC, puede suministrar el remedio al dogmatismo inflexible de la nulidad de pleno derecho y, en concreto, a la posibilidad de ser alegada con éxito por cualquiera que obtenga provecho con ella. Hasta puede, si no desde luego justificar que nadie pueda invocar el motivo de nulidad por él mismo originado, sí algo parecido, algo que dé un sentido más razonable al interés legítimo de manera que coincida con el protegido por la norma violada o, por lo menos, que no sea exactamente el contrario del protegido por la norma cuya vulneración se invoca, y ello pese a que nuestros dogmas sobre la nulidad de pleno derecho y sobre

\footnotetext{
${ }^{45}$ Me parece, por lo que aquí he tratado de reflejar pálida y parcialmente y por otras muchas razones que no procede recoger porque no se relacionan de ninguna forma con el nemo auditur, que es necesario reconsiderar o hasta reconstruir la teoría de las nulidades del Derecho administrativo, como ya han comenzado hacer las mentes más lúcidas de la doctrina civilista con la nulidad de los contratos propugnando, entre otras cosas, la aceptación de nulidades de pleno derecho relativas. Sobre todo, ello encuentra brillante desarrollo en la ya reiteradamente citada obra de M. PASQUAU LIAÑO, Nulidad y anulabilidad del contrato, donde, además, se da noticia de otros intentos en esa misma dirección. Para lo aquí analizado son interesantes sobre todo pp. 225 y ss. Entre otras aportaciones valiosas que no debieran pasar inadvertidas para la teoría del Derecho administrativo, cuestiona el mismo concepto puramente procesal de interesado -interés en que prospere la acción de nulidad, interés de todo el que obtiene un beneficio con la nulidad-, apuntando la posibilidad de construir un concepto sustantivo o material de interesado en cuya virtud sólo estarían legitimados para pedir la nulidad de pleno derecho aquellos que tuvieran un interés coincidente con el protegido por la sanción de nulidad. Con ello y profundas correcciones de la teoría asentada de las nulidades que no tienen, según explica, verdadero fundamento, llega a construir una categoría de nulidades de pleno derecho, pero relativas, sobre todo para los casos de vulneración de normas imperativas de naturaleza protectora de una de las partes y para los casos de nulidad por defecto de forma. Además, y esto también es de interés para nuestro objeto, afirma que la nulidad de pleno derecho no es incompatible con la aplicación de la doctrina de los actos propios, aunque así se afirme generalmente: «... carecen de sentido los reparos que con tanta frecuencia doctrina y jurisprudencia oponen a la virtualidad del principio (de los actos propios) en este ámbito» de la nulidad (pp. 247-248).

Una reconsideración de este tipo me parece oportuna también en el Derecho administrativo. Si no se hace, como mínimo, habría que delimitar de otra forma los supuestos de nulidad de pleno derecho de los actos administrativos pues es equivocado entender que deben ser todos los de vicios graves o los que lesionan los valores superiores (p. ej. derechos fundamentales), si eso conduce a que cualquier interesado en la nulidad pueda alegarla aunque no tenga ningún interés en la regularidad del acto. Y a falta de todo ello, el art. 106 LRJPAC, y, por lo que ahora importa, la equidad, deberá mitigar los excesos de la nulidad de pleno derecho.
} 
DA-2002, núms. 263-264. MANUEL REBOLLO PUIG. Nemo auditur propriam turpitudinem allegans e...

la legitimación conduzcan a otra cosa. Si la equidad tiene que ver, según se dice, con la apreciación de la justicia por el hombre medio, estoy seguro de que la equidad aprueba y hasta exige que no se declaren nulidades que benefician precisamente al que la norma violada no quería proteger que, a veces, es el mismo que la infringión ${ }^{46}$. Así que, en suma, no es tan errada toda la jurisprudencia contencioso-administrativa del nemo auditur, que ha escrito Derecho (o equidad) con renglones torcidos, pero en latín; que ha buscado la equidad pero que, sintiendo pudor de presentarla como tal -en uno de los pocos casos en que podría haberlo hecho así (art. 106 LRJPAC) - la ha revestido con un aforismo, brocardo o máxima que no tiene gran cosa que ver y que hasta la desvirtúa, pero que suena bien y le da una prestancia científica y un brillo que la modesta y humilde equidad no tiene. En este caso, al menos, me parece que los tribunales administrativos sí pueden alegar la torpeza y, por mi parte, alego la propia, por si lo que queda dicho es equivocado.

\section{ÍNDICE BIBLIOGRÁFICO}

\section{LIBROS}

Aguilar Ros, R. en Piñar MaÑas, J. L., (dir.), La reforma del procedimiento administrativo. Comentarios a la Ley 4/1999, de 13 de enero, Dykynson, Madrid, 1999.

Albaladejo, M., Derecho civil, I, vol. $2^{\circ}, 14^{\mathrm{a}}$ ed., Bosch, Barcelona, 1996.

Albaladejo, M. y Díaz Alabart, S. (dir.), Comentarios al Código Civil y Compilaciones Forales, tomo XII, vol. $2^{\circ}, 2^{\mathrm{a}}$ edic., Edersa, Madrid, 1995.

${ }^{46}$ Permítaseme decir, medio en broma, que late en esa jurisprudencia sobre el nemo auditur la misma idea elemental de justicia que en la famosa «ley de la ventaja» del fútbol por la que, quien ha cometido una falta, no se beneficia si, pese a ella, el equipo que la ha sufrido goza de una posición más favorable que la que tendría con su señalización y la interrupción del juego; o por la que no se anula un gol conseguido tras el penalti del equipo batido; o por la que, pese a la alineación indebida del derrotado, no se anularía el partido terminado con un 5-0 para colocar en su lugar sólo un 3-0 que beneficiaría al incumplidor. Con estas licencias futbolísticas, que espero que se me disculpen, pretendo poner de relieve elementalmente que tiene que haber mecanismos para que la aplicación de las normas no consiga un efecto distinto y hasta opuesto al que persiguen: las normas protegen determinados intereses y es absurdo que, por su aplicación mecánica y ciega, se acepte en casos determinados que acaben por perjudicar exactamente a los intereses que protegían y cumpliendo en la práctica la finalidad contraria de aquella para la que están previstas. Eso es lo que ocurre a veces con la nulidad de pleno derecho y la consecuente legitimación para ser alegada por cualquiera que tenga interés en conseguir la anulación. 
Alonso IbáÑEZ, Ma. R., Las causas de inadmisibilidad en el proceso contencioso-administrativo, Civitas, Madrid, 1996.

Beladiez Rojo, M., Validez y eficacia de los actos administrativos, Marcial Pons, Madrid, 1994.

BocANegra SiERRA, R., Lecciones sobre el acto administrativo, Civitas, Madrid, 2002.

Castillo Blanco, F., Estudios sobre la contratación en las Administraciones Públicas, Cemci, Granada, 1996.

Castillo Blanco, F., La protección de confianza en Derecho Administrativo, Marcial Pons, Madrid, 1998.

Cosculluela Montaner, L., Manual de Derecho administrativo, $12^{\text {a }}$ ed., Civitas, Madrid, 2001.

De Laubadère, A., Moderne, F. y Delvolvé, P., Traité des contrats administratifs, $2^{\mathrm{a}}$ ed., LGLJ, París, 1983.

Díez-Picazo Ponce de León, L., prólogo al libro de Wieacker, F., El principio general de la buena fe, Civitas, Madrid, 1982.

Díez-Picazo PONCE DE LEÓN, L., La doctrina de los propios actos. Un estudio crítico sobre la jurisprudencia del Tribunal Supremo, Bosch, Barcelona, 1963.

García de Enterría, E. y Fernández, T. R., Curso de Derecho administrativo, tomo I, $10^{\text {a }}$ ed., Civitas, Madrid, 2000.

GarCía Luengo, J., El principio de protección de la confianza legítima, Civitas, Madrid, 2002.

GonZÁlez PÉREZ, J. El principio general de la buena fe en el Derecho administrativo, $2^{\mathrm{a}}$ ed., Civitas, Madrid, 1989.

GonzÁlez Navarro, F., Derecho administrativo español, tomo III, Eunsa, Pamplona, 1997.

GonzÁlez Pérez, J. y González Navarro, F., Comentarios a la Ley de Régimen Jurídico de las Administraciones Públicas y del Procedimiento Administrativo Común, Civitas, Madrid, 1997, II.

Gordillo, A., Tratado de Derecho administrativo, tomo 3, El acto administrativo, $5^{\text {a }}$ ed., Depalma, Buenos Aires, 2000.

Lacruz Berdejo, J. L., Moreno Luna, A., Delgado Echeverría, J. y Rivero Hernández, F., Elementos de Derecho civil, II, Derecho de obligaciones, vol. segundo, $2^{\mathrm{a}}$ ed., Bosch, Barcelona, 1987.

LÁzaro Carreter, F., El dardo en la palabra, Círculo de Lectores, Barcelona, 1997.

López Merino, F., La notificación en el ordenamiento jurídico español, Cemci, Granada, 1987.

MaIral, H. A., La doctrina de los propios actos y la Administración pública, Depalma, Buenos Aires, 1988.

PASQUau Liaño, M., Nulidad y anulabilidad del contrato, Civitas, Madrid, 1997. 
Paz-Ares Rodríguez, C., Díez-Picazo Ponce de León, L., Bercovitz, R. y Cordech, P. S. (dir.), Comentario del Código Civil, $2^{\mathrm{a}}$ ed., Ministerio de Justicia, Madrid, 1993.

POUYAUD, D., La nullité des contrats administratifs, LGDJ, París, 1991.

Rebollo Puig, M., El enriquecimiento injusto de la Administración pública, Marcial Pons, Madrid, 1995.

RIVERO YSERN, E., La interpretación del contrato administrativo, Instituto García Oviedo, Sevilla, 1997.

Vedel, G., Derecho Administrativo, trad. española, Aguilar, Madrid, 1980.

\section{ARTí́culos}

Baño LeÓn, J. Mª ., «Proyecto de Ley de Contratos de las Administraciones Públicas», Anuario del Gobierno Local, 1995.

Cerdá Olmedo, M., «Nemo auditur propiam turpitudinem allegans», Revista de Derecho Privado, 1980.

García dE ENTERRÍA, E., «La doctrtina de los actos propios y el sistema de lesividad», $R A P$, núm. 20 (1956).

Morell OcaÑa, L., «La lealtad y otros componentes de la ética institucional de la Administración», REDA, núm. 114 (2002).

PiÑAR MAÑAS, J.L., «El sistema de garantías para la efectiva implantación de la apertura de la contratación pública comunitaria», en la obra colectiva La protección jurídica del ciudadano (procedimiento administrativo y garantía jurisdiccional). Estudios en homenaje al Profesor Jesús González Pérez, Madrid, 1993.

Rodríguez Moro, N., «Es obligado el pago del importe de las obras realizadas en favor de un Ayuntamiento aunque el contrato se hubiere celebrado por el Alcalde con infracción de la normativa legal», Revista de Estudios de la Vida Local, núm. 202 (1981).

SAINZ Moreno, F., «La buena fe en las relaciones de la Administración con los administrados», RAP, núm. 89 (1979).

SARMIENTO RAMíreZ-EscudERO, D., «El principio de confianza legítima en el Derecho inglés: la evolución que continúa», $R E D A$, núm. 114 (2002). 